\title{
International project finance: review and implications for international finance and international business
}

\author{
Jakob Müllner ${ }^{1}$
}

Received: 24 January 2017 / Accepted: 9 March 2017 / Published online: 22 March 2017

(C) The Author(s) 2017. This article is an open access publication

\begin{abstract}
This literature review analyzes the global phenomenon of international project finance (PF) as both a management and finance instrument, allowing practitioners to realize large scale infrastructure projects in high risk contexts. After describing the characteristics of PF, its historical origins and its unique benefits for empirical inquiry, I summarize the findings of academic research from an interdisciplinary perspective. Based on this integration of Finance, Management and International Business research, I discuss the theoretical implications for each field that emanate from PF. Finally, I identify possibilities for future research and propose a more balanced, interdisciplinary academic treatment of PF.
\end{abstract}

Keywords Project finance - Megaprojects - Capital structure · Foreign direct investment $\cdot$ Risk management $\cdot$ Literature review

JEL Classsification F210 $\cdot$ F230 - G320 • M160 - G390

\section{Introduction}

Throughout history, mankind has strived to create monumental landmarks in infrastructure and engineering, consistently exceeding the frontiers of what has been technically, organizationally and financially possible. The construction of the Suez Canal, for example, involved complexities that eventually led to cost-overruns of $1900 \%$ (Flyvbjerg et al. 2009); and yet the project was eventually realized, in part,

Jakob Müllner

jakob.muellner@wu.ac.at

1 Department of Global Business and Trade, Institute for Export Management, Vienna University of Economics and Business (WU Vienna), Vienna, Austria 
because of innovative project finance (PF) structures in place (Beidleman et al. 1990). Modern history provides abundant examples for equally impressive landmarks such as the Burj Khalifa skyscraper, the EURO-Tunnel, the Hong Kong-Zhuhai Bridge, or the Ichthys oil field, offshore of Australia in which a consortium of oil MNCs financed the exploitation of one of the world's largest underwater natural gas resources, using almost 34 billion USD in capital. In 2015 alone, a total of 275 billion USD loans were invested in PFs (Project Finance International 2016). Many of these projects were implemented in high-risk environments, such as the Chad-Cameroon oil pipeline (Esty 2004a), or the Petrozuata oil field in Venezuela (Esty 1999b, 2004a).

As a natural consequence of the technical, managerial and political risks involved in many of these megaprojects, both management and financing require equally innovative strategies. While PF practice has evolved considerably in recent decades, Management and Finance scholarship have not kept up with this development. Despite globally growing importance, PF has been somewhat under-represented in research (Esty 2003, p. 29; Sawant 2010, p. 1037). This is even more surprising since several reputable authors including Harvard Finance scholar Benjamin Esty and Oxford's Management professor Bent Flyvbjerg have highlighted the unique, empirical benefits of PF for academic research (Esty 2004b; Flyvbjerg et al. 2009; Kardes et al. 2013; Subramanian and Tung 2016).

The separation of a large and complex infrastructure investment into a financially and organizationally independent project company allows researchers to observe managerial strategies and their outcomes more clearly, and without the empirical distortions emanating from multiple investments within a corporate balance sheet (Esty 2004b; Gatti et al. 2013; Subramanian and Tung 2016). At the same time, the enormous complexity and scale of PF investments make them an ideal research site for managerial decisions at the frontiers of what is economically possible (Flyvbjerg 2014a; Flyvbjerg et al. 2003, 2009; Kardes et al. 2013).

In this structured review, I seek to analyze PF from an interdisciplinary perspective, but with a focus on International business (IB) research. As such, the paper fills important gaps in the literature. Previous reviews on PF have mostly been textbook publications on either financial (Esty 2003, 2004a; Gatti 2013; Yescombe 2014) or managerial practice (Flyvbjerg et al. 2003; Flyvbjerg 2014a, b, c, d), without crossfertilization or discussion of reciprocal implications. In particular, there is no literature review to date that focuses explicitly on the implications of PF on IB scholarship. Second, all of these publications were conceptual in nature, focusing on practical characteristic of PF. To date, there is no systematic literature review that discusses empirical findings in a structured manner. Finally, most of these publications were directed at practitioners and students. As such, they did not elaborate on theoretical implications that emanate from PF for scientific research (two finance related exceptions being Esty (1999a, b, 2004a, b)).

The aim of this literature review is to integrate finance, management and IB research on PF, to identify reciprocal theoretical implications and derive an interdisciplinary research agenda. Along with PF practice, the fields have developed considerably over the years, with changing emphasis, theories and applications. In addition to this within-field heterogeneity, the questions posed by researchers across disciplines vary considerably. A quantitative literature review would not adequately capture such com- 
plexities. Therefore, I rely strongly on a qualitative literature review to develop the theoretical contributions and the broader research agenda. However, I also present aggregate and quantitative data on PF research to give a broad overview of the field.

Following a literature-based definition and discussion of $\mathrm{PF}$ as a distinctive form of investment, I systematically review the literature on PF in Management, IB and Finance disciplines. Overall, these findings provide considerable support for the benefits of PF in high risk environments. I then discuss the implications of PF research for the most relevant theories in these disciplines. Therein, I make two important contributions: First, by applying theory to the phenomenon, I deductively identify important questions for PF practice and ultimately for PF research. Second, and in a more inductive approach, I analyze the structures used in PF to derive important theoretical implications for the disciplines under review. In closing, I identify the most promising avenues for further scientific inquiry and make a case for more interdisciplinary research on PF.

\title{
2 Project finance definition and characteristics
}

From a practitioner's perspective, the most important definition of PF comes from the Basel Committee on Banking Supervision ${ }^{1}$ :

\begin{abstract}
Project finance may take the form of financing of the construction of a new capital installation, [...] The lender is usually paid solely or almost exclusively out of the money generated by the contracts for the facility's output [...]. The borrower is usually an SPE (Special Purpose Entity) that is not permitted to perform any function other than developing, owning, and operating the installation. The consequence is that repayment depends primarily on the project's cash flow and on the collateral value of the project's assets. (Basel Committee on Banking Supervision 2004, p. 61)
\end{abstract}

The primary addressees of BASEL II are banks who provide debt to a project. The accord outlines two constituting characteristics of PF: First and unlike traditional corporate finance, a PF loan is awarded to a separate project company that is financially and organizationally separated from the sponsoring firms. Second, in true PF, banks relinquish the right to recover the loans from the equity sponsors in the event of default. Loan securitization is based solely on the projected cash-flows of the project and not on the creditworthiness of the investing sponsors. As a result, banks take on extensive risks related to the non-performance of the project.

Focusing strongly on cash-flow related lending and non-recourse characteristics, the Basel II definition fails to fully incorporate the equity providers' view. In this regard, academic scholarship has been somewhat more inclusive, highlighting the pivotal importance of risk sharing strategies as a third component of PF (Brealey et al. 1996, p. 25; Nevitt and Fabozzi 2000, p. 1). Most PF investments involve large scale investments in location-specific assets and in highly uncertain contexts (Esty and

\footnotetext{
1 This definition also serves as a basis for environmental and social standards in PF banking, often referred to as the Equator Principles. For empirical research on the effects of the Equator principles on projects and banks I refer to Scholtens (2000), Haack et al. (2012) and O'Sullivan and O'Dwyer (2015).
} 
Sesia 2011; Hainz and Kleimeier 2006). For corporate finance, this makes projects prohibitively risky. As a result, they seek to identify the most important sources of risk a-priori and devise risk management strategies (e.g. contracts, equity participation) to address them. Such strategies transfer certain sources of risk to parties that are more capable of managing them (Beidleman et al. 1990; Brealey et al. 1996; Farrell 2003; Miller and Lessard 2001). In combination with separation of the project and non-recourse, cash flow-related lending, risk sharing allows sponsors to make investments that otherwise would be economically unfeasible. By outsourcing the project to a legal entity without recourse, sponsors protect their main operations from costs of financial distress (Subramanian and Tung 2016). In addition, the high level of leverage increases return on equity, and makes the PF investment a lucrative business for sponsors (Brealey et al. 1996).

A necessary precondition for PF is that sponsors and lenders reach a-priori agreements on the distribution of cash-flows that is mutually beneficial (Esty 1999b). Such an agreement is difficult to reach, especially when projects involve a large number of participants with different interests. As a result, and as a fourth characteristic, PFs involve very high transaction costs related to a-priori legal and planning costs. Larger projects commonly involve a multitude of parties on the equity side such as facility developers, operators, suppliers and contractors (Brealey et al. 1996; Gatti 2013; Yescombe 2014). These sponsors are complemented on the debt side by relatively powerful lending consortia which often include commercial banks, institutional investors, export credit agencies and multilateral development banks. They contribute almost $80 \%$ of capital and seek high levels of control over project management. While equity providers are motivated by the potential upsides of projects, banks capitalize on high fees and relatively fixed interest rates. This asymmetry in incentives creates a potential source of conflict and considerable agency costs, especially in the event of financial distress.

In large projects with high socio-economic importance, additional tiers of agency conflicts arise (Flyvbjerg et al. 2009). For example, PFs often incorporate buyers and local stakeholders in their capital, or contractual structure (e.g. offtake agreements, environmental compensation, and social programs). Most prominently, the local government often takes on a crucial role as capital provider, owner and/or guarantor (in these cases PF is often referred to as private-public partnerships or PPP). In international PF, where foreign firms seek to implement a large-scale project, foreign exploitation collides with local ownership of resources and territorial sovereignty. This results in a fifth characteristic of international PF: high risk of obsolescing bargaining (Vernon 1971). Once the facilities are installed, the local stakeholders can abuse the vulnerability of investors to renegotiate contracts and extract cash-flows from the investment. Large projects, in particular, are exposed to considerable pressure from the media, NGOs, local communities and ultimately taxpayers (Henisz 2002, 2014; Marquis and Raynard 2015). Given these risks, the question remains as to why PF has succeeded in becoming one of the most important financing strategies for high-risk investment. 
Table 1 Sector distribution of global PF volume. Source: (Project Finance International 2016)

\begin{tabular}{lcc}
\hline Sector & Mio. USD & Percent $(\%)$ \\
\hline Power & 106,338 & 38 \\
Transportation & 61,903 & 22 \\
Oil and gas & 55,753 & 20 \\
Petrochemicals & 13,592 & 5 \\
Industry & 12,097 & 4 \\
Leisure and property & 11,203 & 4 \\
Mining & 8637 & 3 \\
Water and sewerage & 6049 & 2 \\
Telecommunications & 1064 & 0 \\
Waste and recycling & 312 & 0 \\
Total & 276,950 & 100 \\
\hline
\end{tabular}

\section{History and market for project finance}

The origins of international PF can be traced back as far as the Middle Ages, when the British Crown financed silver mines through non-recourse loans from Italian merchant banks (Esty et al. 2014; Kensinger and Martin 1988). However, wide-spread practice of PF did not start until the early twentieth century oil field exploration in the United States (Esty et al. 2014). Modern PF, as a financial risk management tool developed in the 1980s, when it became the primary means of financing large energy projects in the US. Between 1991 and 2012, PF raised over 2.5 trillion USD to fund more than 6000 international projects (Subramanian and Tung 2016).

The financial crisis in 2008 has led to a considerable contraction in PF lending and a redistribution of projects towards the Asian continent (Esty et al. 2014). However, with the exception of the project bonds market, PF lending has proven remarkably resilient to financial market turmoil. By 2013 PF loans recovered from 249.3 billion USD in 2009, to a pre-crisis level of 415 billion USD (Esty et al. 2014). ${ }^{2}$ This swift recovery highlights the durability of $\mathrm{PF}$ under high risk environments.

Table 1 illustrates the distribution of investments across regions. It shows the comparatively high shares of investments in high risk-regions in Africa and Asia and supports the common claim that PF is particularly useful in in countries with weak institutions. For example, in 2014, more than a quarter of investments in the Americas were directed towards high risk countries in South America (Project Finance International 2016). The most comprehensive sources of PF information are the databases maintained by Dealogic and Thomson Reuters (Byoun et al. 2013; Corielli et al. 2010; Lerner et al. 2008). Within their sample of investments, the average Economist Intelligence Unit political risk score of host-countries (33) was comparable to South Africa.

Table 2 summarizes the sector distribution of PF investments. The largest sector for $\mathrm{PF}$ is power generation (38\%), followed by transportation (22\%) and oil and gas (20\%).

\footnotetext{
2 Statistics can vary to some degree based on source and because some institutions report PF lending only, while others report total PF volume including equity investment.
} 
Table 2 Regional distribution of global PF volume in mio. USD. Source: (Project Finance International 2016)

\begin{tabular}{lrrrrrrr}
\hline Year/region & \multicolumn{1}{c}{2009} & 2010 & 2011 & 2012 & 2013 & 2014 & 2015 \\
\hline Americas & 19,277 & 24,357 & 38,305 & 39,397 & 51,368 & 93,191 & 93,276 \\
Africa/middle east/central asia & 18,321 & 18,731 & 17,440 & 23,631 & 37,295 & 22,126 & 32,520 \\
Europe & 44,447 & 66,015 & 67,443 & 46,298 & 52,715 & 70,466 & 75,670 \\
Austral/asia-pacific/japan & 56,421 & 97,510 & 91,317 & 88,199 & 62,762 & 76,679 & 75,482 \\
Total & 138,468 & 206,615 & 214,506 & 197,526 & 204,140 & 262,463 & 276,949 \\
\hline
\end{tabular}

These sectors share a number of characteristics: First, they require sizeable investments that justify the considerable legal and administrative costs that are involved in PF financing. Second, they involve location-specific assets which, once installed cannot easily be recovered from a potentially risky sovereign territory. Third, their outputs are reasonably stable, allowing for a-priori valuation and cash-flow based lending.

Scholarship predicts a growing importance of PF. On the one hand, developed governments face budgetary constraints and have become increasingly dependent on private sector funding. On the other hand, developing countries are eager to close the infrastructure gap (Esty et al. 2014). At the same time, the re-emergence of expropriation concerns provides a strong incentive for private companies' incentives to use PF, as a means of addressing political risk.

In addition to economic scale of PF, there are strong socio-political and arguments that highlight the importance of PF. Despite justified criticism of ex-post development effects and the distribution of wealth (Arndt et al. 2012; Lenz et al. 2017), PF has allowed developing economies to construct infrastructure projects, which would not have been possible through public funding (Brealey et al. 1996; Kleimeier and Versteeg 2010; La Cour and Müller 2014). The critical views on PF also underline the pressing need for further research on PF. Therein, researchers can benefit from the unique empirical setting.

\section{Empirical benefits of project finance}

The dearth of empirical research on PF is surprising, since there are compelling arguments that PF provides a uniquely suitable "research site" for both financial and managerial research (Esty 2004b, p. 214).

First, the organizational and financial isolation of investments, with limited lifetime provide a "clear window" through which to study managerial decisions and their outcomes (Esty 2004b, p. 214). I refer to this as the clarity benefit of PF. In the study of firm behavior, multiple projects are "commingled" within a balance-sheet, and these projects are often exposed to very different risks (Subramanian and Tung 2016, p. 154). The portfolio of projects changes over time and it becomes more difficult for researchers to trace back variations in performance to past decisions. Because of the multiplicity of projects, the risk of omitted variables and spurious findings is higher in the analysis of firms compared to PFs. 
$\mathrm{PF}$ provides an attractive controlled environment free from various influences that are present in corporate finance. As a stand-alone entity, PF's structural details [and the performance outcomes] are easily observable to outsiders, whereas structural decisions of corporations can be obscured by other corporate activities (Byoun and Xu 2014, p. 124; Esty 2004b, p. 217).

The same isolation benefit applies to the local context. While firms commonly operate in a multitude of institutional contexts, the institutional environment of a PF can be isolated much more effectively. This facilitates measurement and improves causal inference. As a result, PF lends a uniquely clean setting for the analysis of institutional effects on the governance and performance of foreign investments. In addition, the special purpose nature of PF means that the project company and its' governance structure is initiated as a clean sheet and for a clearly defined special purpose. Hence, it is influenced to a much lesser extent by pre-existing structures and corporate imprinting (Marquis 2003; Marquis and Tilcsik 2013). In PF, partners join to create a new venture under a tailored governance structure. They are assembled as a function of the specific project rather than past interaction. As a result of superior clarity, PFs lend themselves in a unique way to quantitative empirical studies. Support for the clarity benefit comes from empirical results in quantitative finance. Studies have shown that PF loans are priced more effectively than corporate loans (Blanc-Brude and Strange 2007; Kleimeier and Megginson 2000). The separation of the project from the companies' reduces information asymmetries between the lender and the investment and allows for more efficient credit appraisal. The same information benefit manifests when researchers use PF, rather than companies, as research sites. In sum, PF provides a superior research setting that is free from portfolio effects, institutional overlap and historic precedents and clearly defined in terms of project context.

In addition to empirical clarity, the application of PF at the frontiers of managerial, financial and technological possibilities provides opportunities for researchers to ask questions which do not apply to day-to-day corporate decisions; or which are simply not observable in less extreme contexts. I refer to this as the complexity benefit of PF. Megaprojects introduce managerial challenges, which are potentially valuable for both Finance and Management research (Esty 2004b; Flyvbjerg 2014a; Kardes et al. 2013). For instance, whereas traditional research on inter-firm cooperation focuses almost exclusively on dyadic forms of cooperation such as R\&D alliances (Ahuja et al. 2009; Eisenhardt and Schoonhoven 1996; Gulati 1995; Lavie and Rosenkopf 2006). PFs allow researchers to analyze cooperative investments with a much larger number of participants. For example, there are compelling theoretical arguments that the social dynamics of such multi-partner alliances may be very different from fairly simple dyadic settings (Chung and Beamish 2012; Heidl et al. 2014; Mohr et al. 2016). Flyvbjerg et al. (2009) show that the multi-partner nature of large projects leads to collective delusion and deception, as multiple participants seek self-interest in situations of diluted accountability. This results in what he refers to as, the "iron law of megaprojects: Over budget, over and over again" (Flyvbjerg 2011, 2014b, p. 11)

Unlike the clarity benefit, the complexity benefit materializes most often in qualitative research, which is more capable of capturing such questions. For example, 
case studies of mega-projects have a long and fruitful tradition in PF research (Ahola and Davies 2012; Chen 2009; Doh and Ramamurti 2003; Esty 1999b, 2001, 2004a; Gkeredakis 2014; van Marrewijk 2007). As Oxford University scholar Bent Flyvbjerg states in his appraisal of megaprojects:

Never has systematic and valid knowledge about megaprojects therefore been more important to inform policy, practice, and public debate in this highly costly area of business and government. (Flyvbjerg 2014b, p. 7)

In sum, PF provides both clarity and complexity benefits for empirical research and promises new applications for Finance and Management theories, as well as managerially relevant insights. Despite the economic relevance and the empirical benefits of PF, research on PF has been scarce and fragmented. In the following, I review PF research in Finance, Management and IB.

\section{Review of research on project finance}

I carried out a structured literature review of published journal contributions, using Thompson Reuters Web of Science. The search was limited to papers which either have the terms "project finance" and/or "megaproject" in their title, or as the author-provided topic. ${ }^{3}$ The search yielded 192 papers that met the criteria. Furthermore, contributions which were not categorized as "Management", "Business Finance", "Economics" and "Business" were excluded. I also excluded publications which were not ranked by the Association of Business Schools Ranking (ABA Version 2015), reducing the sample to 78 published articles. I then analyzed the references cited in the papers for articles with more than five occurrences and included these publications if they were sufficiently addressed PF-related topics. This additional step generated a further 21 papers from sources outside Thompson Reuters Web of Science, in particular from the Journal of Applied Corporate Finance. In a first step, I quantitatively analyze the sampled publications in Tables 1, 2, 3, 4, 5 and 6 .

As evident from the distribution of papers in Tables 3, 4, 5 and 6, academic research picked up on $\mathrm{PF}$ as an important research context long after its economic boom in the 1980s. One practical reason for this delay was data availability. During a time in which empirical research using larger datasets and more sophisticated computational methods flourished, company level-data was becoming more publicly available. Project data, on the other hand, was collected by a selected number of banking services firms, which were available only at high cost.

The breakdown according to publication sources also illustrates the leadership role of Finance Journals have taken in PF research. Using the R bibliometrix package, a summary of author-supplied keywords was generated and is presented in Table 7. The analysis reveals a broad mix of managerial and financial topics. It lends support to the pivotal roles of risk management, governance, capital structure, and contracts in PF.

\footnotetext{
3 Alternative spellings such as "project financing" and "mega-project", "infrastructure finance" and "infrastructure investment" were also included.
} 
Table 3 Timeline of PF publications in ABS ranked journals. Source: Thompson Reuters Web of Science

\begin{tabular}{|c|c|}
\hline Year & Publication count \\
\hline 1976 & 1 \\
\hline 1980 & 1 \\
\hline 1987 & 1 \\
\hline 1988 & 2 \\
\hline 1989 & 1 \\
\hline 1990 & 2 \\
\hline 1991 & 3 \\
\hline 1995 & 2 \\
\hline 1996 & 3 \\
\hline 1997 & 1 \\
\hline 1998 & 4 \\
\hline 1999 & 1 \\
\hline 2000 & 2 \\
\hline 2002 & 2 \\
\hline 2003 & 4 \\
\hline 2004 & 3 \\
\hline 2005 & 1 \\
\hline 2007 & 7 \\
\hline 2008 & 3 \\
\hline 2009 & 3 \\
\hline 2010 & 4 \\
\hline 2011 & 2 \\
\hline 2012 & 7 \\
\hline 2013 & 10 \\
\hline 2014 & 6 \\
\hline 2015 & 11 \\
\hline 2016 & 10 \\
\hline 2017 & 2 \\
\hline Total & 99 \\
\hline
\end{tabular}

It also highlights the important IB elements of foreign direct investment and political risk.

In a second and more qualitative step, I analyze the publications in historical order before summarizing their implications for related fields. The earliest publications on PF related to practitioner articles in Harvard Business Review and Sloan Management Review from Wynant (1980), Beidleman et al. (1990) and Wells and Gleason (1995). These publications emphasize the leadership role of practice in PF research. From an academic perspective, the origins of PF research can be traced back to two seminal publications: On the Finance side, Shah and Thakor (1987) derived formal proof that PF is a superior form of investment in high-risk context, because it allows sponsoring firms to create a tailored capital structure and isolate project risk. At around the same time, 
Table 4 Distribution of PF publications by journals.

Source: Thompson Reuters Web of Science

Asterisks indicate in ABS ranking in 2015

Table 5 Authors of PF publications in 3 star ABS ranked journals. Source: Thompson Reuters Web of Science

Asterisks indicate authors with additional practitioner articles, textbooks and case studies
Journal

Publication

count

\begin{tabular}{lc}
\hline International Journal of Project Management** & 11 \\
Journal of Applied Corporate Finance* & 7 \\
Project Management Journal* & 4 \\
World Development*** & 4 \\
Journal of Financial Intermediation**** & 3 \\
European Financial Management*** & 3 \\
Journal of World Business $* * * *$ & 3 \\
Financial Management*** & 3 \\
Journal of Finance***** & 3 \\
Organization Studies**** & 2 \\
International Journal of Production Economics*** & 2 \\
Regional Studies*** & 2 \\
European Journal of Operational Research**** & 2 \\
Long Range Planning*** & 2 \\
Journal of Financial and Quantitative Analysis**** & 2 \\
Energy Policy** & 2 \\
Harvard Business Review*** & 2 \\
Journal of the Operational Research Society*** & 2 \\
Review of Quantitative Finance and Accounting*** & 2 \\
Other (37) & 2 \\
\hline & 2 \\
\hline
\end{tabular}

\begin{tabular}{ll}
\hline Author & Count \\
\hline Gatti* & 7 \\
Esty* & 2 \\
Steffanoni & 2 \\
Megginson* & 2 \\
Byoun & 2 \\
Borgonovo & 2 \\
Caselli & 2 \\
Kleimeier* & 2 \\
Corielli & 2 \\
Ramamurti & 2 \\
Davies & 2 \\
Doh & 2 \\
Xu & 2 \\
Others (100) &
\end{tabular}


Table 6 Discipline distribution of PF publications in ABS ranked journals. Source: Thompson Reuters Web of Science

\begin{tabular}{lc}
\hline Discipline & Publication count \\
\hline Finance & 34 \\
Management & 31 \\
Other* & 25 \\
International Business & 25 \\
Accounting & \multicolumn{2}{c}{6} \\
Total & 29 \\
\hline
\end{tabular}

* Other includes Development economics, sector specific journals (engineering, transport) and Business Ethics and economic policy

Table 7 Key word count. Source: Thompson Reuters Web of Science

\begin{tabular}{|c|c|c|}
\hline Rank & Author & Keywords \\
\hline 1 & Project Finance & 23 \\
\hline 2 & Megaproject & 8 \\
\hline 3 & Risk management & 4 \\
\hline 4 & Governance & 3 \\
\hline 5 & Political risk & 3 \\
\hline 6 & Capital & 2 \\
\hline 7 & Capital structure & 2 \\
\hline 8 & Complexity & 2 \\
\hline 9 & Contracts & 2 \\
\hline 10 & Coordination & 2 \\
\hline 11 & Debt ratio & 2 \\
\hline 12 & Equator principles & 2 \\
\hline 13 & Event study & 2 \\
\hline 14 & Finance & 2 \\
\hline 15 & Foreign direct investment & 2 \\
\hline 16 & Infrastructure & 2 \\
\hline 17 & Innovation & 2 \\
\hline 18 & Project & 2 \\
\hline 19 & Project management & 2 \\
\hline 20 & Public-private partnership & 2 \\
\hline
\end{tabular}

but on a conceptual level, Williamson (1988) published a seminal article encouraging the integration of corporate governance and financial theory in the Journal of Finance. The article bridged interdisciplinary gaps and explicitly connected PF to managerial question of governance, using transaction costs theory. Williamson complements the restrictive formal model of Shah and Thakor (1987) with managerial arguments such as opportunistic discretion, incomplete contracts and ex-post transaction costs. In 
addition, Williamson makes a strong and explicit case for the empirical superiority of project investments:

Whereas most prior studies of corporate finance have worked out of a compositecapital setup, I argue that investment attributes of different projects need to be distinguished. (Williamson 1988, p. 576)

Despite this prominent encouragement, PF research found much more traction in the financial research community.

\subsection{Financial research}

Finance has extended Shah and Thakor (1987) work over the following years. Berkovitch and Kim (1990), John and John (1991), and Chemmanur and John (1996) continued the tradition of formal modelling to include agency cost benefits, tax benefits, and bankruptcy costs in PF. These results were later supported by the formal works on the optimal scope of firms from Leland (2007) and Banal-Estañol et al. (2013). These finance models positioned PF as a superior form of financing for high risk investments, but they strongly focused on financial benefits and applied rather restrictive formal modelling.

In 1996, Brealey et al. (1996) summarized some of these findings in a conceptual publication on the benefits of PF in infrastructure investment. This work was important in that it also acknowledged managerial risk management strategies (i.e. mitigation of political risk), and therein deviated somewhat from the strong finance perspective observed in previous research. Shortly after, Dailami and Leipziger (1997) provided the first major empirical attempt to test formal models in a quantitative study of credit spreads. Using infrastructure projects, they found that host-country environmental factors strongly affect credit risk and pricing. Without explicit mention, their work highlighted the important role of the institutional context of the investment in theoretical and scientific inquiry. However, their study left unanswered the question of the optimal structuring of loans in terms of project vs. corporate finance.

In 1999, Esty documented the benefits of PF in natural resource investments, using the case study of the Petrozuata oil field in Venezuela (Esty 1999b). Despite the high risk of the investment, he argued, project participants had put sufficient risk management instruments in place to not only oversubscribe the bond issue, but to do so at lower cost than through sovereign borrowing. At roughly the same time, Kleimeier and Megginson (2000) put this efficiency claim of PF loans to the empirical test and published a quantitative comparison of syndicated PF loans and syndicated corporate loans. Their remarkable results indicated that $\mathrm{PF}$ loans achieve longer maturities and lower interest rates, despite higher country risk. Ultimately, they provided empirical verification, or support for the formal models in previous publications. Retrospectively, the two publications can be characterized as the climax of PF optimism. Their unanimous diagnosis was that both qualitative and quantitative empirical evidence strongly supported the superiority of PF in financing infrastructure in high risk countries. This PF optimism, however, would later be challenged by episodes of expropriations and intensive stake- 
holder conflicts, which included the nationalization of the famous Petrozuata project described by Benjamin Esty.

Following the works of Esty (1999b) and Kleimeier and Megginson (2000), Finance researchers extended theoretical perspectives on PF. Picking up on work from corporate finance, scholars incorporated real options theory into infrastructure finance and identified non-recourse provisions as a sort of real put option for sponsoring firms (Esty 1999a; Han 2003; Kensinger 1999). Later, Esty and Megginson (2003) teamed up to publish a seminal contribution linking legal institutions to the composition of PF banking syndicates. They integrated arguments from institutional theory and comparative institutional economics into $\mathrm{PF}$ research to explain the formation of partnerships among PF lenders.

At the same time, Esty (2004b) documented his empirical experiences with PF as a clean and undistorted research setting in a conceptual paper, and called for more systematic use of PF in both Management and Finance research. In the paper, Esty (2004b, p. 221) admits that: "large investments frequently fail to achieve their intended financial and operating objectives." This critical view indicates a soft deviation from the optimism of the PF boom in the late 1990s. Another indication of the growing acknowledgement of the fallibility of PF was an increase in publications related to more realistic valuations of projects using methods such as Monte-Carlo simulations (Gatti et al. 2007), and towards more stakeholder-inclusive measures of project value (West 2015). Despite this increasing skepticism, the structural benefits of PF were still undisputed and empirically verified in later quantitative studies (Blanc-Brude and Strange 2007; Dailami and Hauswald 2007; Sorge and Gadanecz 2008; Subramanian and Tung 2016).

Along with the rising popularity of financial contracting theory, the majority of later Finance research extended its focus from capital structure-related benefits to contractual risk management (Byoun et al. 2013; Byoun and Xu 2014; Corielli et al. 2010). Research highlighted the pivotal role of contractual agreements between parties in PF. It also recognized the risk mitigating role of specific project partners, such as international development banks (Hainz and Kleimeier 2012), and reputable lead arranging banks (Gatti et al. 2013).

Overall, financial research provides clear and consistent evidence of the benefits of PF resulting from agency cost reduction, higher debt capacity, lower cost of debt, financial distress and optimized tax shields. The over-arching agreement is that the separation of a project to a separate entity reduces information asymmetry between lenders, allows for tailored capital structure and provides optimal incentives for all participants.

\subsection{Management and IB research}

Management and IB research were late in recognizing the economic and empirical benefits of PF. Additionally, Management research has focused more intensively on the disadvantages or complexities involved in PF, which often serve to explain why so many projects failed despite superior financial structures. 
With the exception of practitioner oriented publications, the first detailed theoretical analysis of PF was conducted by Farrell (2003), using agency theory. While remaining on a conceptual level, his paper discusses the difficulties of cooperation between multiple parties, with different incentives and proposes managerial strategies to reduce such agency costs. In 2007 and 2008, Van Marrewijk extended this line of works with detailed case studies on the role of socio-cultural aspects as critical success factors in large-scale projects (van Marrewijk 2007; van Marrewijk et al. 2008). These works focused much more on the intricacies of coordinating large-scale and complex projects involving numerous, potentially differing actors. Over time, several scholars have developed helpful frameworks for process management, mostly based on qualitative research and case studies (Chen 2009; Davies and Mackenzie 2014). Overall, Management research has shed light onto the inter-partner complexities between the project participants (Gkeredakis 2014), the broader social community (Haack et al. 2012) and onto the psychological fallacies that managers suffer from when faced with failing megaprojects (Flyvbjerg et al. 2009; Kardes et al. 2013). A central scholar within this line of research, was Bent Flyvbjerg from Oxford University, who compiled all of these managerial problems in his handbooks of managing megaprojects and in his empirical work (Flyvbjerg 2014a, b, c, d; Flyvbjerg et al. 2003, 2009). The over-arching narrative is that megaprojects suffer from fragmented self-interest, dilution of accountability, and different risk preferences and time horizons between parties (Flyvbjerg et al. 2009, p. 179).

Overall, Management research has provided detailed insights into the functioning, or indeed the malfunctioning, of megaprojects. As opposed to Finance researchers, Management scholars have predominantly addressed the hidden, ex-post cost of PF. Their work has provided important explanations as to why project fail, or suffer from enormous delays and cost-overruns, despite optimal financial structuring. As such, Management scholarship provides valuable complements to financial research which has focused mostly on the benefits of a-priori structuring and less on the ex-post costs.

Among all three disciplines, IB research has appreciated the empirical benefits of PF to the least extent. This is surprising since the cross-border nature and high risk of PF provide clear IB implications. Early works by Lyles and Steensma (1996) mostly address intercultural problems in the acquisition of projects and remain on a rather conceptual level. Much later, in 2003, Ramamurti and Doh introduced PF as an important strategic tool to mitigate host-country risks international investments (Doh and Ramamurti 2003; Ramamurti and Doh 2004). Focusing strongly on obsolescing bargaining between the host-country government and the investing MNCs, they make a compelling case for PF as an alternative to more prominently advocated strategies, such as local government participation or joint-ventures with local partners. Vaaler et al. (2008) extended this political risk-perspective towards other sources of risk, providing a multi-layered framework for investment risks and linking these risks the capital structure of a particular investment. Using large-sample, quantitative analysis, this work combines agency and institutional theory to analyze a number of core IB strategies such as ownership structure, international experience and liability of foreignness. More importantly, however, their work makes a strong case for the role of capital structure in mitigating investment risk of a specific investment; a strategic instrument that had not been sufficiently considered in IB scholarship before. 
Building on this work, Sawant (2010) provided further empirical evidence on PF as a particularly effective entry mode in situations of high political risk and obsolescing bargaining. Comparing corporate investments with PF investments, he established a direct link between country-level risk and the propensity to use PF. Similar to Vaaler's contribution, Sawant's works applied capital-structure benefits of PF to high risk investments. However, they fell short of a holistic framework that included other benefits of PF like contractual risk management.

Most recently, Müllner (2016) made an attempt to create a more holistic framework of risk management strategies in markets entry. Accordingly, the use of PF allows investing MNCs to more efficiently diversify host-country risk, because of higher debt capacity and risk isolation. Using tailored capital structure, firms can share risks, tailor incentives. Also, PF provides instruments to address specific sources of risk with contractual instruments (e.g. offtake agreements, supply agreements, equipment procurement contracts and export credit guarantees, operation and maintenance contracts). Finally, the cooperative structure of the investment allows sponsoring MNCs to create a strong consortium that collectively mitigates political risk. The empirical analysis illustrates that PFs use a myriad of risk-management strategies that extends beyond the traditional repertoire of IB strategies.

In sum, IB research has made late advances in recognizing PF as an efficient entry mode for large investments in high risk environments. In particular, it has highlighted the possibility of addressing the obsolescing bargaining problem. Essentially, PF can be used by MNCs as a substitute for high-control entry modes that require extensive investments in the host country. As a result, they also carry substantial downside risk.

Figure 1 provides a condensed, historical landscape of PF publications in all three fields based on their time of publication, quality of the publishing journal (bubble size) and citation counts (vertical axis). Table 8 summarizes publications, their primary discipline, theoretical basis, type and main contributions. In a next step, I use this reviewed evidence to derive theoretical implications of PF for the most common theories in the fields of Finance, Management and IB.

\section{Theoretical implications for management and finance theory}

The phenomenon of PF has been identified as an important research context by both Finance and Management. However, the theoretical implications that result from PF have not been explicitly outlined, especially for the field of IB. The two research streams have evolved in isolation without mutual acknowledgement of the valuable insights of the other. In the following section, I analyze the phenomenon of PF from both perspectives and derive important theoretical implications. While the focus of the analysis is on Management and IB theory, I begin the review with interdisciplinary and financial perspectives on PF.

\subsection{Interdisciplinary perspectives}

Agency theory (Jensen 1986; Jensen and Meckling 1976) transcends both financial and managerial research on PF. The multi-party nature makes PF ideal research sites for 


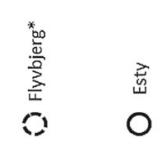

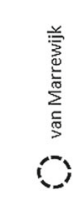

$\overbrace{}^{\frac{2}{2}}$

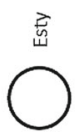

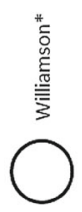

○

$\stackrel{\text { 竞 }}{\circ}$

范

氜

ปั

:

总营 $\frac{0}{60} \frac{5}{5}$ نํ.

$\wedge$.

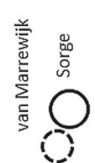

(1)

$\bigcap_{0}^{\infty}$

先 $\frac{\pi}{0}$

.

论 은

穿 $\frac{2}{8}$

m

当.

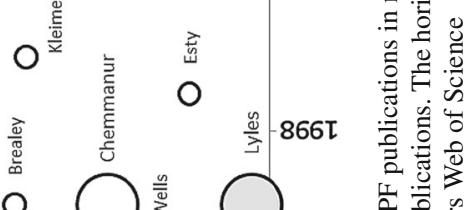

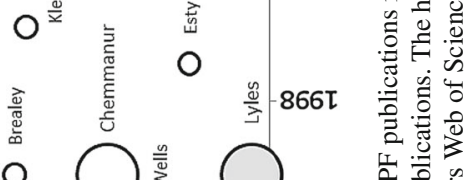

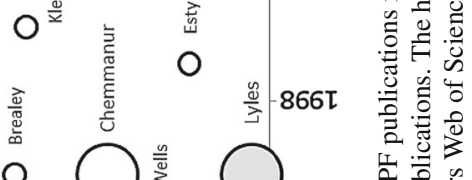

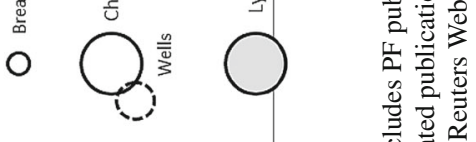

$\exists$

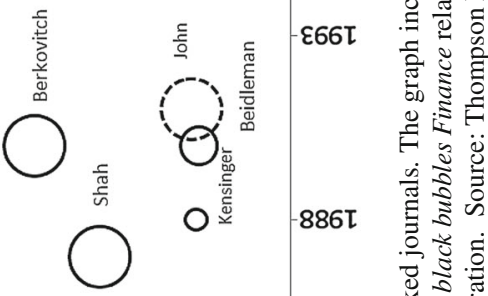

흔

ป

를

n:

थิ जै

- E86I $\cong \frac{0}{0}$

章

氜

흘

है है

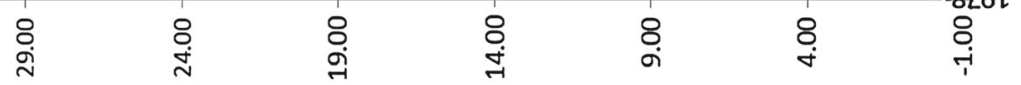

范

¿ $\stackrel{1}{ \pm}$

苟

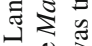

$-\stackrel{0}{3}$

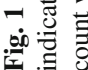


multi-layered agency problems (Farrell 2003). Agency costs occur on several levels: between the sponsoring firms, between the creditors of the project, between these two groups and ultimately between the project and its local stakeholders. Finance theory has been very optimistic about the agency advantages of PF, based on the assumption that the separation of the project allows for optimization of financial incentives. Brealey et al., for example, conclude that: "The dominant reason for the growing importance of project finance in funding infrastructure investment is that it addresses agency problems in a way that other forms of financing do not." (Brealey et al. 1996, p. 27)

Similarly, institutional economics (Coase 1998; North 1995) have somewhat merged finance theory and Management perspectives, in this case, related to countrylevel opportunism. The assumption is that "institutions are formed to reduce uncertainty in human exchange" (North 1995, p. 18). PF provides the case in point. Its structure is tailored to the socio-economic environment in which the investment is made. Related research has shown that the pricing of loans (Dailami and Leipziger 1997) and the composition of lending syndicates differ as a function of the institutional environment (Esty and Megginson 2003). Furthermore, it has found that the choice of $\mathrm{PF}$ as a particular governance structure is directly related to the legal protection of investors (Subramanian and Tung 2016). In the Finance field, both agency and institutional economics literature focus clearly on the a-priori structuring of projects, without much acknowledgement or analysis of post-investment dynamics between agents and institutions. The dominant narrative is that PF ought to be put in place a-priori to reduce risk from individual actors, or the broader institutional context.

Management research applying these theories has been somewhat more skeptical. Kardes et al. (2013) and Flyvbjerg et al. (2009) have analyzed troubled projects and come to the conclusion that in situations of distress, otherwise aligned incentives between partners fall apart and lead to considerable agency costs. When expectations are not met, all partners seek to reduce their sunk costs at the same time. This defensive behavior can lead to extensive cost overruns, construction delays and excessive legal costs. The Berlin-Brandenburg Airport, to provide a practical example, has almost tripled in costs, and construction has been delayed by more than six years (Reuters 2015).

In addition to differing incentives between partners on a micro-level, Management research highlights the role of macro-level cultural and institutional differences between partners that can affect the likelihood of agency conflicts. Financial research should equally extend its conceptualization of agency to include partner macrocharacteristics, in order to explain variations in project structures (i.e. local institutions, norms and culture) (Byoun et al. 2013). IB research, on the other hand, should make full use of the rich setting of PF to advance our understanding of agency costs between individual participants, groups of participants and between local and foreign project stakeholders. In particular, IB research has focused exclusively on the equity investors in their analysis of cross-border investments, disregarding the pivotal role of lenders and the potential conflicts that can influence a foreign investments resulting from debtequity agency costs. Agency theory and institutional theory have been applied to PF by both Finance and Management scholarship. Other perspectives have not succeeded in bridging the gap between disciplines. In my review I start with financial theories because of their earlier origins and higher prevalence in PF research. 


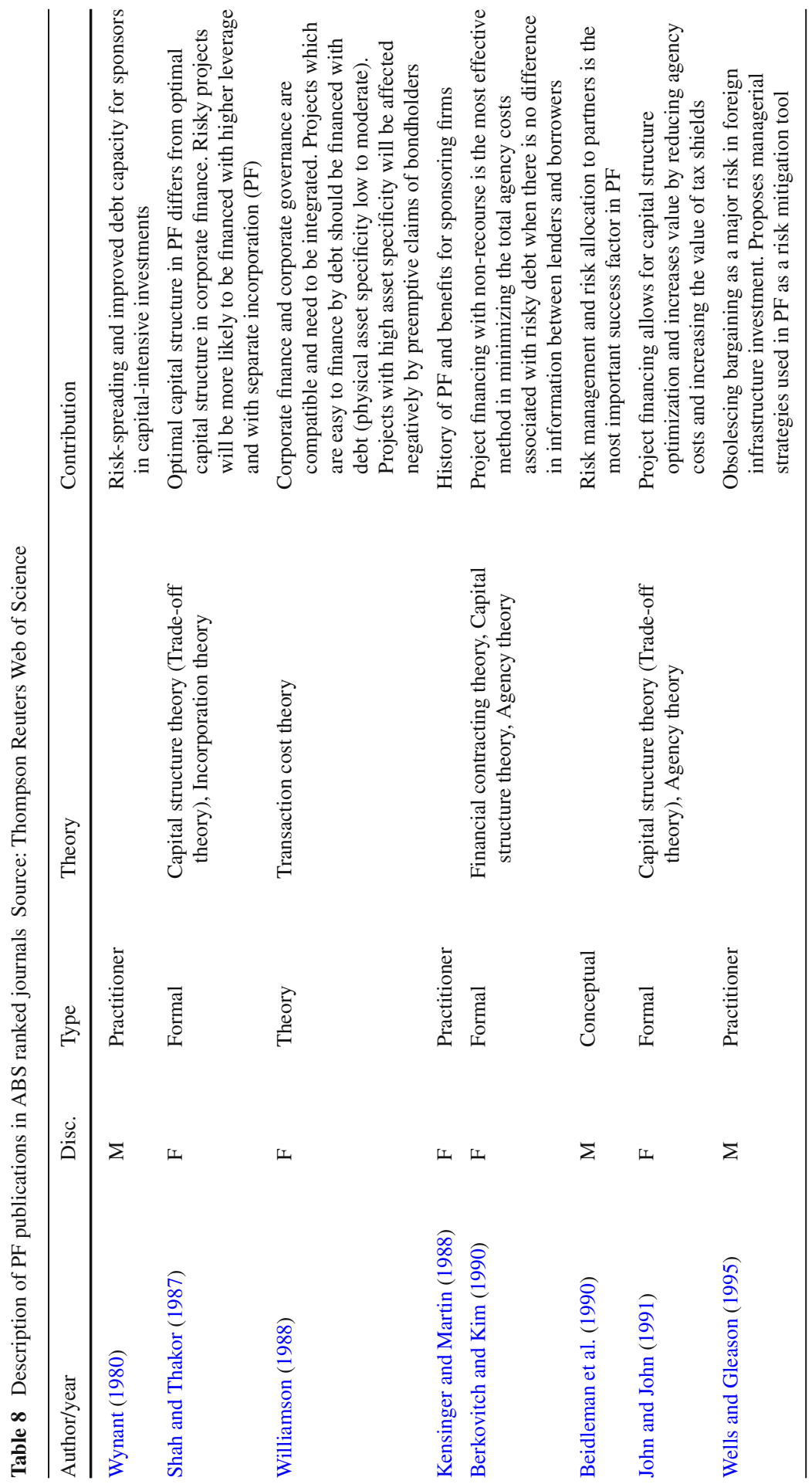




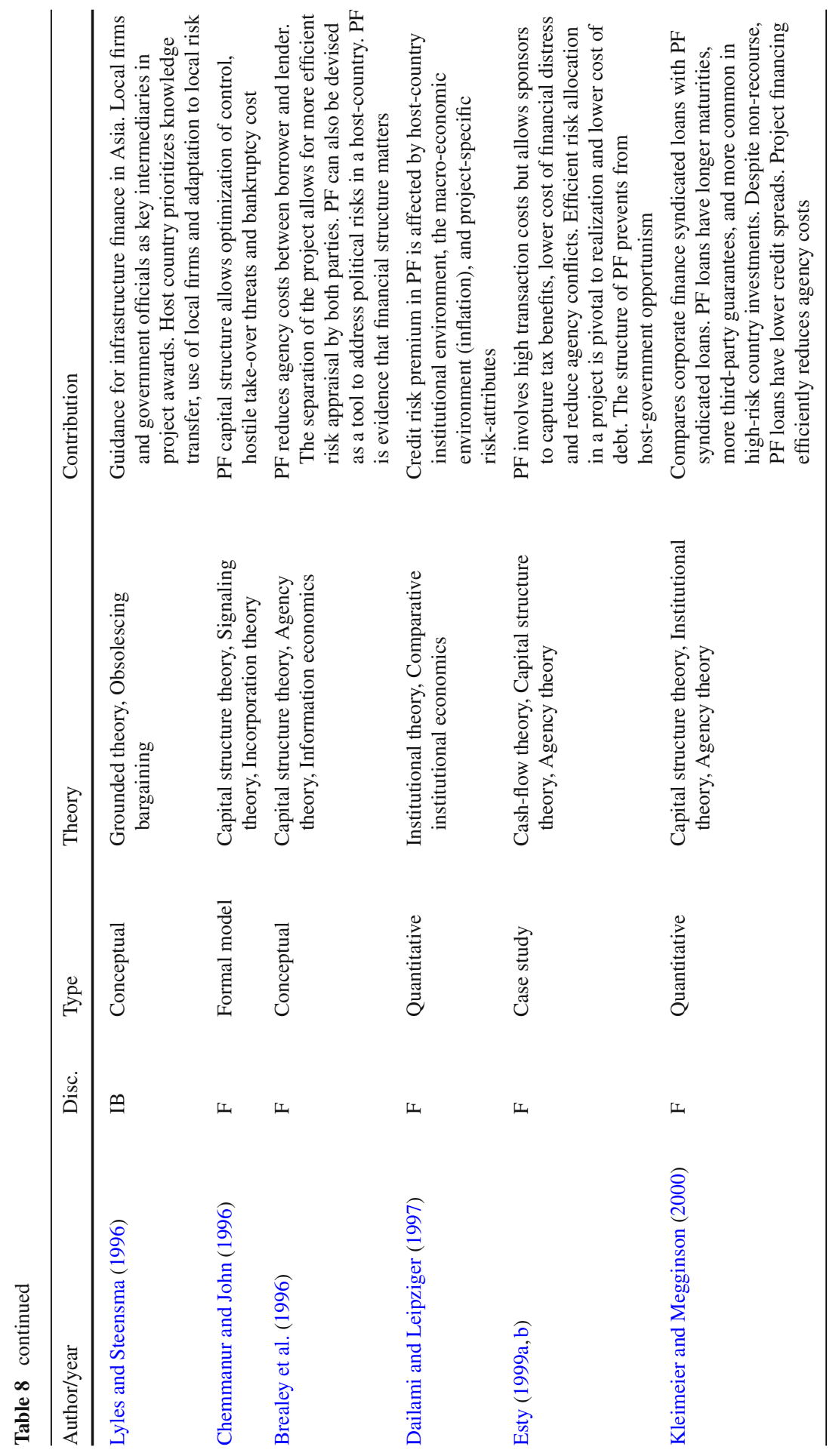




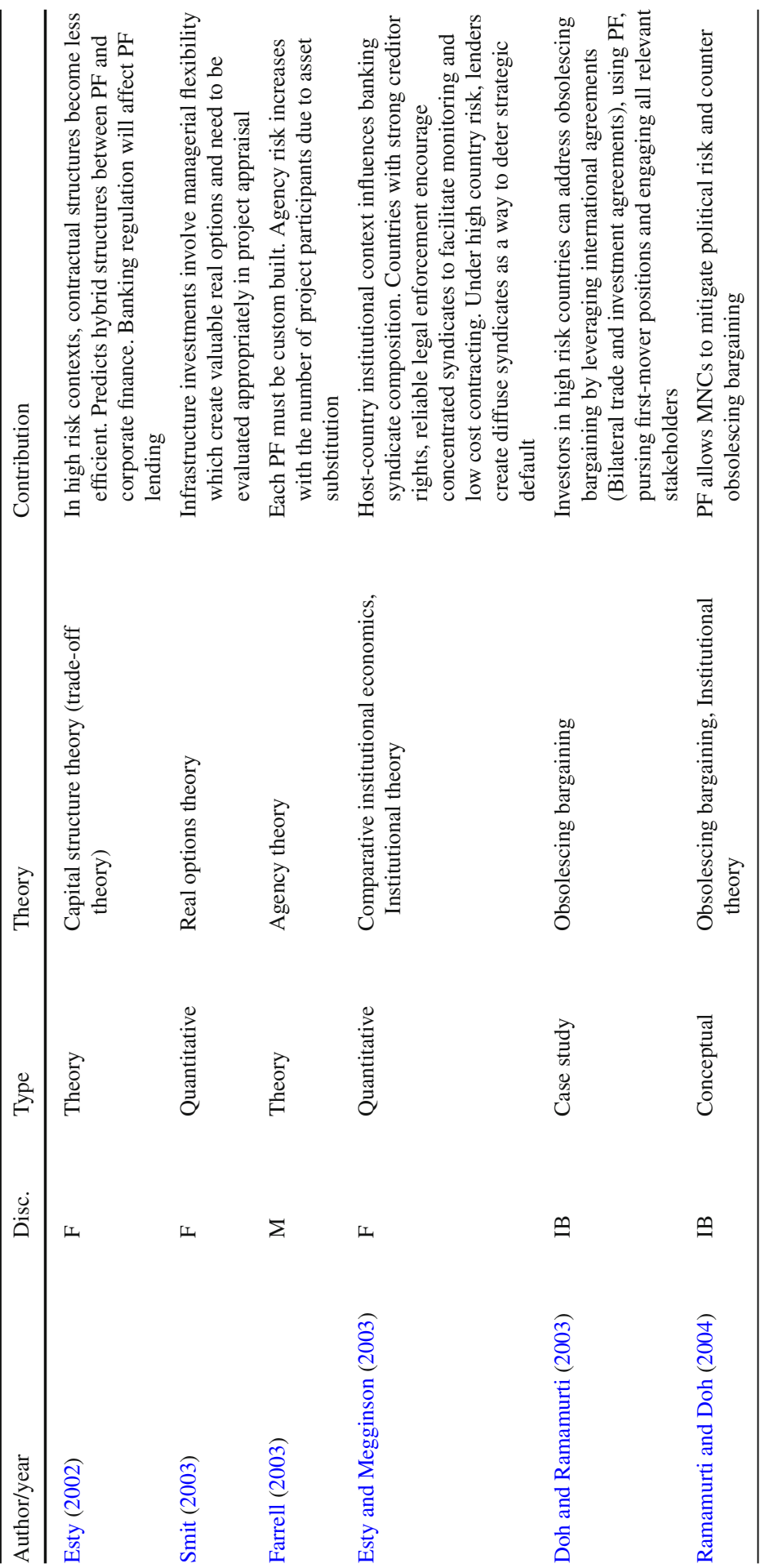




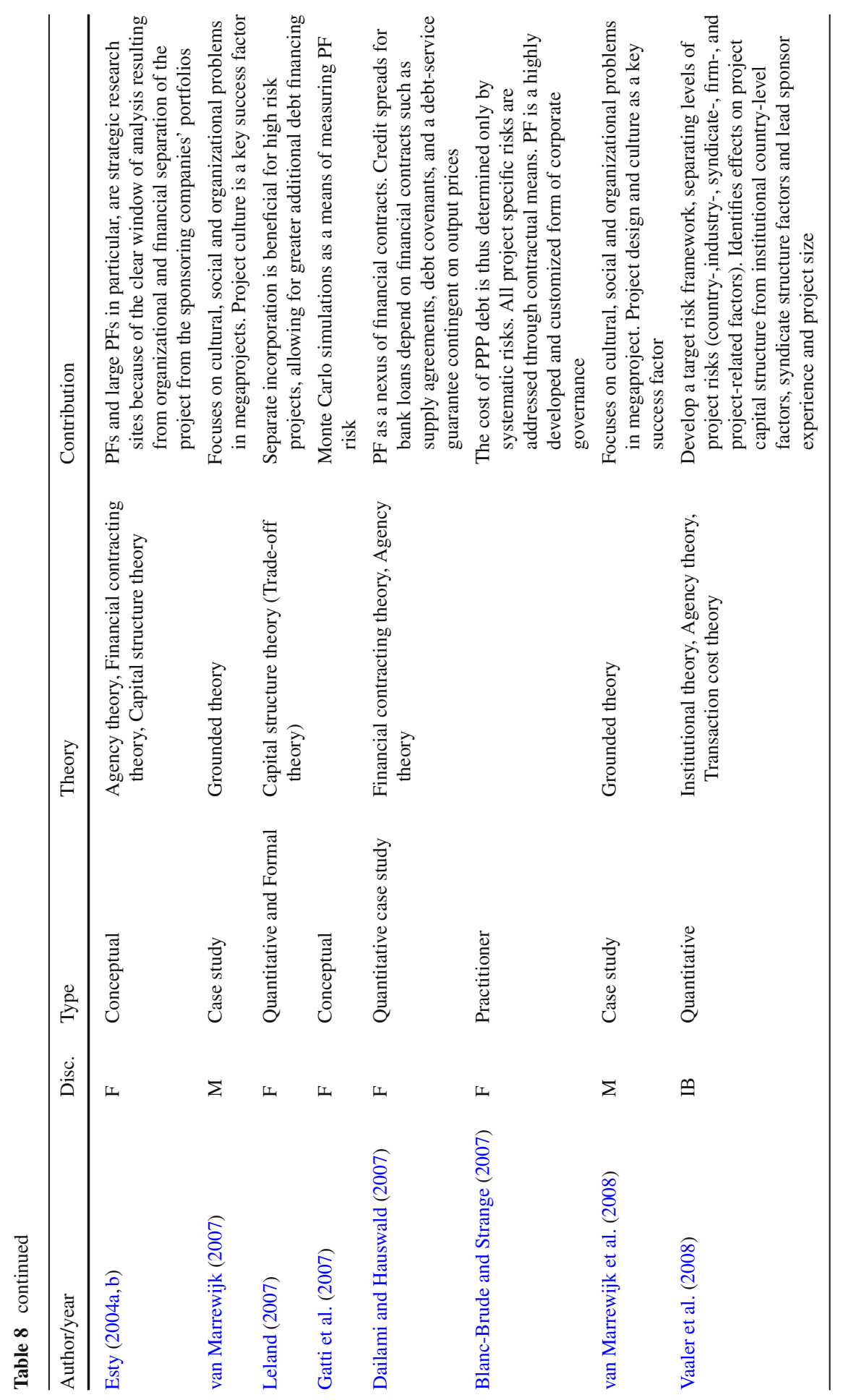




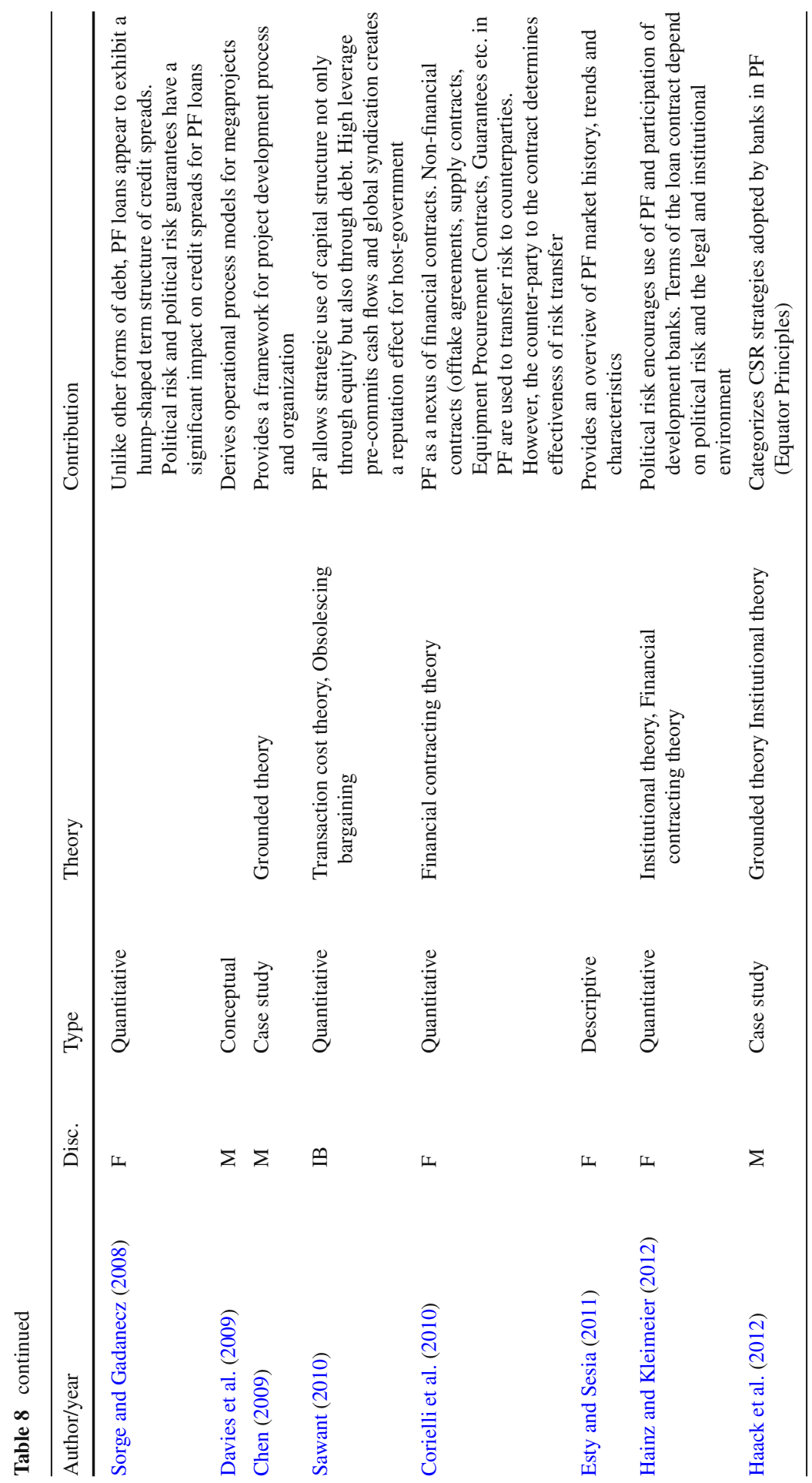




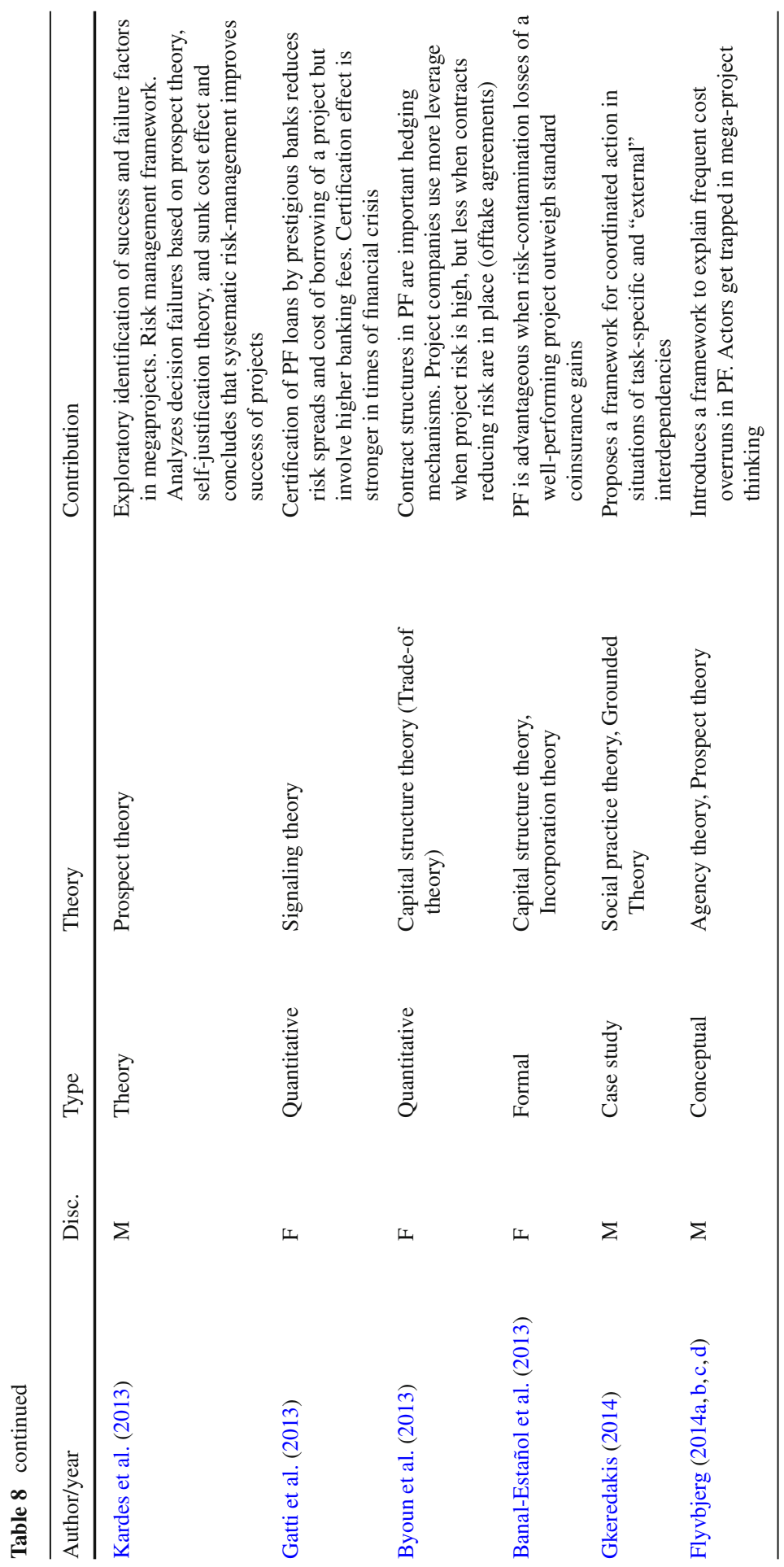




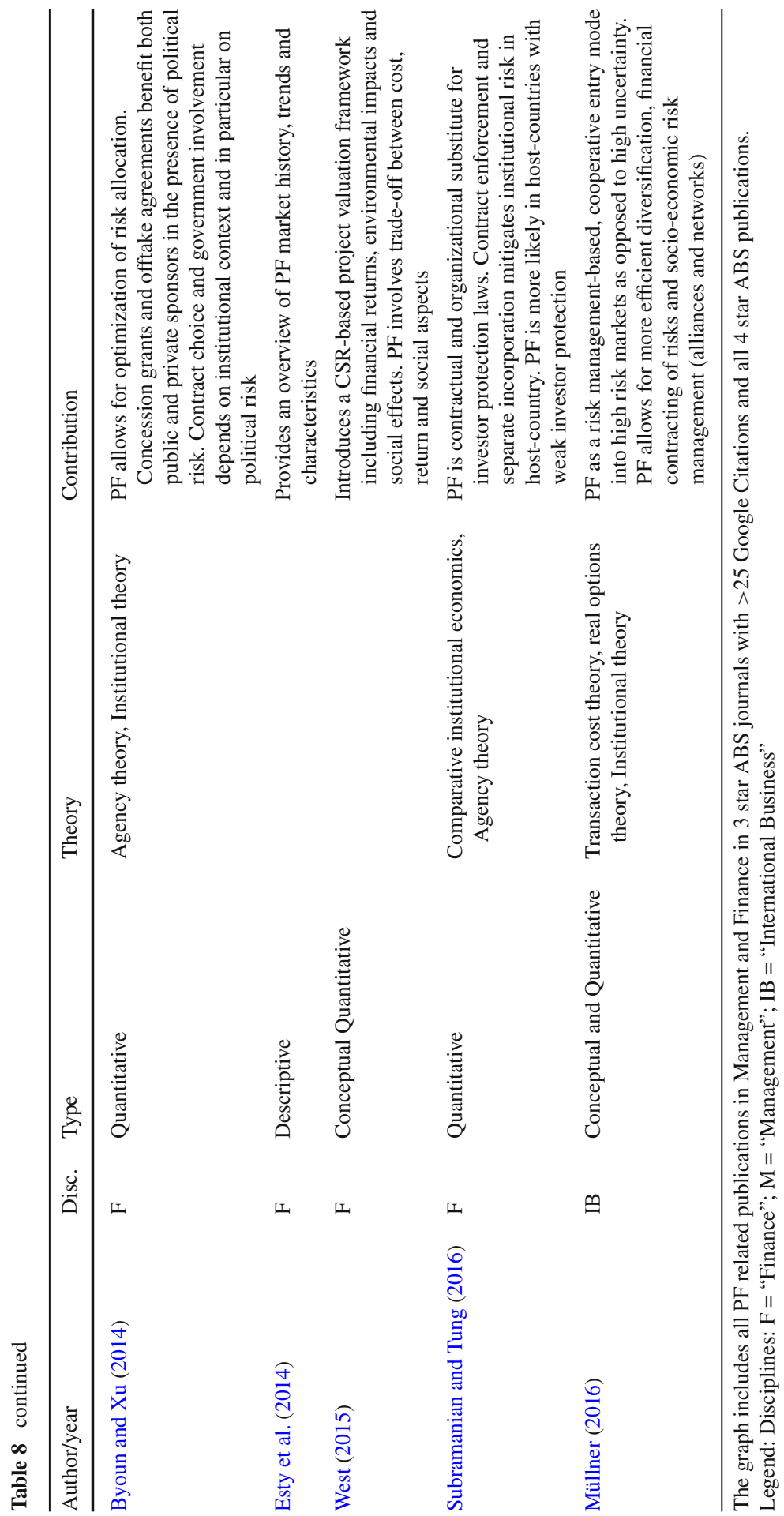




\subsection{Financial theory}

In 1958, Modigliani and Miller (1958) published their seminal contribution on capital structure. At the core is the formal proposition that firm value in perfect capital markets is not affected by the financial structure of investments (Brealey et al. 1996; Esty 1999b, 2004b). Under such conditions, the decision to finance a project in a stand-alone structure or within the corporate balance sheet should not matter. PF provides evidence that the underlying assumptions of Modigliani and Miller's irrelevance proposition do not hold for large infrastructure investments in high-risk countries. Extensive costs of financial distress, along with tax benefits from debt, create a large incentive for sponsoring firms to create separate legal entities for risky projects that enable them to isolate project risk, while accepting potentially higher transaction cost. This implies that PF can help to overcome market inefficiencies, in particular those that have been studied by institutional researchers in the field of IB. While there has been some progress in Finance research on incorporating such market inefficiencies related to legal and political risk, many questions remain as to the origins of market inefficiencies. Finance research would strongly benefit from incorporating the rich toolkit of institutional and IB research. Concepts such as institutional and cultural distance (Berry et al. 2010) can help to explain ex-post agency costs between partners, or between the project location and partners. Equally, concepts such as liability of foreignness and legitimacy strategy (Bell et al. 2010, 2012) can help to explain why so many projects fall victim to the iron law (Flyvbjerg 2011, 2014b, p. 11).

By far, the most commonly used theories to explain the superiority of PF in Financial research are capital structure theories. The pecking-order theory of capital structure (Myers 1984) postulates that information asymmetries between firms and lenders lead to a preference for debt in risky investments. In PF, sponsoring firms seek to maximize the use of debt, while at the same time reduce information asymmetry between sponsors and borrowers by isolating the project. Addressing risks of the project a-priori allows them to keep cost of debt at a sustainable level (Brealey et al. 1996). By negotiating non-recourse with lenders, sponsors can isolate project risk, reduce costs of financial distress, conserve debt-capacity and maximize tax benefits, as argued by trade-off theory (Kraus and Litzenberger 1973). Capital structure theories are hence strongly supported by PF practice. However, Managerial research poses the question as to how a static capital structure, that is established a-priori and follows a pre-determined repayment schedule, over a considerable project life-time, can be an efficient risk management instrument in a dynamic institutional environment. Management literature has addressed such dynamics, in particular in the event of financial distress. It suggests that partners' and incentives may change and capital structure incentives may lose their efficiency. For example, while equity participation of the host-government may prevent opportunistic incentives a-priori (Inoue et al. 2013; James and Vaaler 2013), IB research has provided compelling evidence that such incentives may flip if the political landscape changes (Fisman 2001; Fisman and Wang 2015; Siegel 2007). This managerial perspective positions institutional dynamics as potential boundary conditions of capital structure as a risk mitigation tool.

Among the more recent theoretical perspectives on PF, real options theory has received considerable theoretical backing from PF researchers. Non-recourse provi- 
sions, they argue, grant investing firms a valuable "walkaway put option" (Esty 2003). Real options theory extends finance perspectives beyond static capital structure and incorporates the value of managerial flexibility (Kogut and Kulatilaka 1994; Li and Rugman 2007; Naylor et al. 2015). As such, a real option methodology promises valuable applications in Management research. Management and IB scholars have limited their inquiry to traditional methodologies and could greatly benefit from incorporating real options analysis in their methodological toolkit. ${ }^{4}$

Contracting theory (Hart 2001; Kaplan and Strömberg 2003) provides a crucial link between the financial and managerial perspectives of PF by recognizing that financial contracts are incomplete and that economic actors behave opportunistically (Agmon 2006). The predominant view is that PF constitutes a "nexus of contracts" that addresses risks before the initiation of the project (Blanc-Brude and Strange 2007, p. 97; Corielli et al. 2010, p. 1317; Dailami and Hauswald 2007, p. 249; Esty 2004b, p. 218; Esty and Megginson 2003, p. 40; Williamson 1988, p. 569). In PF, contracts with various stakeholders such as suppliers, the host-government, banks, customers, builders and operators (Byoun and Xu 2014; Corielli et al. 2010) are devised under conditions of information asymmetry. Each of these contracts is designed to transfer specific risks to those participants most capable of managing them (Beidleman et al. 1990; Brealey et al. 1996; Farrell 2003; Miller and Lessard 2001). IB research in particular could benefit from this perspective. Focusing almost exclusively on equityrelated rather than contractual risk-management, IB research has failed to acknowledge the complementarities between these strategies (Müllner 2016). PF clearly illustrates that control through equity or internalized hierarchies are not a panacea to uncertainty. Settings like PF provide a fruitful context in which to analyze the potential effects of formal and relational contracts in foreign investments (Poppo and Zenger 2002).

\subsection{Management and IB theory}

The financial origins of PF have somewhat hampered academic interest in PF within the Management domain. This is particularly unfortunate since, similar to the Finance discipline, PF can help to refine IB and Management theories, explain inconsistent empirical findings and provide valuable insights into the management of high-risk investments.

Among the most prominent theories in IB research (Hennart 1982; Rugman 1981; Teece 1977, 1986; Williamson 1976, 1979, 1996), transaction cost theory has helped to explain firms' scope and investment decisions. Even though Williamson (1988) himself linked transaction cost theory to financial structure and to PF, scholarship in Management and IB research have not followed up on this argument. According to Williamson, firms create governance structures to protect transactions from opportunism (Williamson 1988, p. 569). Transaction cost theory focuses on three char-

\footnotetext{
4 An illustrative application in IB is, for example, provided by Naylor et al. (2015) who show that real options present in PF, or in political risk guarantee can influence investment value and performance.
} 
acteristics of transactions: uncertainty, frequency and asset specificity ${ }^{5}$ (Williamson 1979, p. 239). A prominent application of transaction cost theory in IB is the entry mode decision theorized on by, amongst others, Anderson and Gatignon (1986). Accordingly, firms rely on market transactions (export, licensing etc.) as a "default strategy" (Anderson and Gatignon 1986, p. 8; Hennart 2010, p. 258). However, when a transaction involves specific assets and external uncertainty, transaction cost logic predicts that firms internalize the transaction within their hierarchy. In essence, the Anderson and Gatignon (1986) model predicts high-control entry modes for investments with transaction-specific assets in uncertain environments. This prediction has been criticized both on theoretical and empirical grounds (Crook et al. 2013; David and Han 2004; Ghoshal and Moran 1996; Rugman and Verbeke 2003).

Modern international PF clearly falls in the former category of high risk investments. The assets deployed to the foreign country are location-specific and involve considerable sunk costs (Esty 2002, p. 77; Esty 2003, p. 27). In addition, a large share of PF investments is dedicated to countries with considerable political risk. However, in contradiction to transaction cost theory, PF cannot be categorized as a high-control market entry strategy. Commonly, sponsoring firms share ownership with a multitude of stakeholders. Non-recourse loans involve extensive control rights for debt providers. When predetermined performance indicators are not met, the loan covenants stipulate that the lending syndicate takes over control of the project (Byoun et al. 2013; Subramanian and Tung 2016). In sum, PF contradicts transaction cost logics. Sponsoring firms do not engage in transaction cost minimization. Rather, they accept excessive transaction costs resulting from the contractual complexity and higher interest rates of PF finance. The benefits of PF materialize in a reduction of risk (rather than costs). On the bright side, PF can help to explain these inconsistent findings in IB on the high-risk high-control hypothesis (David and Han 2004). The concerted use of risk management in PF (diversification, contracts and socio-economic) can substitute for control, or hierarchy in a risky foreign investment (Müllner 2016). In essence, PF supports Crook et al. (2013, p. 73) in their claim that: "managers have found innovative ways to reduce TCs involved [...] and that these innovations allow for greater control, without increasing the degree of integration."

$\mathrm{PF}$ also has implications for the resource based view of the firm (Barney 1991). The perspective has been a cornerstone of strategic management literature, with extensive applications in the international context ranging from market entry decisions (Brouthers et al. 2008; Meyer et al. 2009; Varinder and Erramilli 2004), to alliance formation (Das and Bing-Sheng 2000; Koka and Prescott 2002). In PF, both of these strategies are combined. Project sponsors actively seek alliances with other sponsors, governments and capital providers, in order to access resources that permit the consortium to reduce the risk of the investment to a sustainable level. While knowledge and technological capabilities certainly have an important effect on the choice of equity partners, PF highlights the role of risk-related resources in international investments (political clout, diversification capabilities, access to guarantees, hedging competence, technological expertise). The non-recourse nature of lending requires sponsoring firms

\footnotetext{
5 Asset specificity is defined as: "the degree to which an asset can be redeployed to alternative uses [...] without sacrifice of productive value” (Williamson 1996, p. 59).
} 
to transfer each source of risks to partners that are capable of carrying this specific risk (Beidleman et al. 1990, p. 47; Brealey et al. 1996, p. 25; Farrell 2003, p. 549; Miller and Lessard 2001). This lends support to the claim that international investments are not solely motivated by TC minimization, but equally by the bundling of complementary resources (Brouthers and Hennart 2007, p. 397; Hennart 2010, p. 259). More intriguingly, the pivotal role of lenders in PF stresses the need to extend the resource bundling argument beyond equity providers and the liabilities' side of an investment (Agmon 2006). In essence, the involvement of global and reputable lending syndicates in PF provides a political umbrella for the risky project (Hainz and Kleimeier 2006, p. 27; Hainz and Kleimeier 2012, p. 288). ${ }^{6}$ This political risk mitigating effect is also supported by research from rating s agencies. According to Moody's (2015), recovery rates on distressed PF loans achieve almost $80 \%$ and the most likely recovery rate is $100 \%$. This supports the claim that PF's strong lending syndicates provide political resources that can be can be accessed to deter strategic default and opportunism by host governments (Müllner 2016).

The predominant theoretical perspective in IB research on PF has been the obsolescing bargaining concept (Ramamurti 2001; Vachani 1995; Vernon 1971; Woodhouse 2006). It describes the fundamental shift of power towards the host-government, once a location-specific investment has been made. As a consequence of the location-specific nature of assets, the host government can engage in hold-up tactics and extract cashflows from the project (Jenkins 1986; Woodhouse 2006; Wynant 1980). Infrastructure investments are particularly vulnerable to such obsolescing bargaining. PF provides important contributions and theoretical extensions to obsolescing bargaining strategies in international investment. Governments in developing countries are dependent on access to financial markets and thus, vulnerable to coercive pressures from global banking syndicates:

The involvement of financial institutions (particularly large international banks) deters host governments from squeezing the IPPs [infrastructure investments] opportunistically to a level that would affect debt coverage. Indeed, every government official interviewed for this study who had been involved in a renegotiation identified debt payments as a hard constraint on their willingness to pressure a project. (Woodhouse 2006, p. 180).

The high leverage used in PF pre-commits cash-flows to fairly powerful banks. This reduces free cash-flows of a project that would be available for opportunistic expropriation and maximizes the repercussions of opportunistic behavior by the hostgovernment (Brealey et al. 1996; Esty 1999b, 2001). At the same time, non-recourse provisions align sponsors interests with those of banks, directing lenders' efforts, to protect an investment against a potentially opportunistic host-government, rather than relying on sponsors' collateral. Therein, PF supports secondary or indirect bargaining strategies in risky foreign investments, as described by resource-dependence scholars (Emerson 1962; Gargiulo 1993; Granovetter 1985). In essence, investing MNCs can

\footnotetext{
6 Both reputable mandate arrangers and multinational organizations have shown they have been able to reduce credit spreads on project loans, which is an indication of a risk mitigating effect (Gatti et al. 2013, p. 32; Sorge 2004, p. 99).
} 
make use of macro-economic dependencies and financial strategies to influence power dependence to their favor (Alcacer and Ingram 2013; Rangan and Sengul 2009).

The last IB theory, for which PF has considerable implications, is institutional theory. A central caveat of financial research is the assumption of efficient capital markets, which often translates into assuming irrelevance differences in institutional configurations across countries (Djankov et al. 2003; Glaeser et al. 2004; La Porta et al. 1998, 1999, 2000). The institutional literature in IB focuses on such institutional impediments and works under the assumption that institutional context and differences affect strategic decisions of firms investing in foreign countries (Kostova 1999; Kostova et al. 2008, 2009; Kostova and Zaheer 1999; North 1981; Scott 1995). Clearly, in PF such local risks of a particular investment effect the decision to use PF as a means of reducing institutional risks (Byoun et al. 2013; Scott et al. 2011). However, the mechanisms proposed in PF differ from those most prominently propagated by institutional IB scholars. Based on the works of DiMaggio and Powell (1983), IB research has identified imitation strategies (Salomon and Wu 2012), local political activism (Nell et al. 2015; Sawant 2012), local equity shares (Chan and Makino 2007) and stakeholder management (Henisz 2014; Henisz et al. 2014), as important strategies to counter institutional risks and reduce the liability of foreignness (Zaheer 1995, 2002). PF often involves more aggressive, power-related strategies to counter institutional divides and risk. For example, projects often involve multinational organizations (Hainz and Kleimeier 2012), financial market protection and strategic jurisdiction as means of addressing weak institutions (off-shore escrow accounts, international arbitration) (Esty 2004a).

The above discussion has shown that PF not only provides support for many of the most common theories used in Finance, Management and IB, but it also highlights important additions and boundary conditions. Based on these theoretical extensions, I now conclude the paper by making a bold attempt to identify the most pressing and valuable avenues for future Finance, Management and IB research.

\section{Research agenda and potential lessons from PF}

Financial research on PF has focused very strongly on the a-priori benefits of structuring investments as PF. Therein, it has not sufficiently acknowledged the ex-post dynamics in complex, multi-partner investments, especially when a project fails to achieve its pre-defined financial goals and as a-priori structures lose their efficiency. Finance research would benefit greatly by integrating findings from Management research and seeking to more thoroughly address deadlocks, cost-overruns and harmful social-dynamics. Ultimately, this would allow Finance to devise more flexible and responsive structures that could improve the efficiency of PF. Including game-theory and real options perspectives more strongly, would enable Finance researchers to learn more about ex-post dynamics of PF and the pitfalls that have resulted in so many project failures.

In addition, institutional perspectives in Finance research have focused almost exclusively on the legal environment of the host-country of the project. IB and Management research, however, have identified inter-partner differences as important barriers 
to efficient collaboration. Following the seminal contributions of Esty and Megginson (2003) and Esty and Megginson (2000), which focused more on the number of banks in a banking syndicate, research should incorporate distances between banks and ultimately between banks and sponsors, as potential determinants of PF structures. In addition, IB scholarship has made considerable advances in measuring more normative institutions in host countries, which could complement the dominant, formal institutions studied by Finance researchers. Acknowledging inter-partner differences with regard to informal institutions and culture would allow finance researchers to explain arising conflicts in PFs and would ultimately lead to a more nuanced understanding of multi-partner collaboration in uncertain environments.

Given the considerably shorter tradition of PF research, there are numerous possible research avenues for IB and Management research. In the following, I focus my discussions on the three most promising, from my perspective. First, PF provides a practical example of how firms devise strategies to address clearly identifiable sources of risk in international investments. In its analysis, IB research has been very much focused on the much broader concept of uncertainty as a determinant of strategy. Early economic scholarship, however, has been very clear on the difference between unmeasurable uncertainty and measurable (and manageable) risks (Knight 1921). IB research would benefit greatly from sharpening its perspective to differentiate between very broad uncertainty and specific sources of risk that are both measureable and manageable (Müllner 2016). This would allow IB to depart from very broad uncertainty related mechanisms such as hierarchy, control equity towards more micro, contractual risk management tools, with high practical relevance. Finance research has found early on that "financial arrangements cannot be viewed in isolation from other parts of the nexus of contracts" (Dailami and Hauswald 2007, p. 275; Fama 1990). A similar, more holistic approach, including contractual and socio-economic risk management, should be applied to internationalization strategy, in order to achieve higher validity and practical relevance. Using the example of PF as a practical reference point, IB research could learn how firms orchestrate complementary risk management strategies in a way that allows firms to realize investments without the use of control or hierarchy.

Second and in a similar vein, PF provides evidence that, contrary to most applications of transaction cost theory, firms do not minimize transaction costs. In fact, transaction cost economics has been criticized for low managerial practicability, its static nature and for providing false normative prescriptions (Ghoshal and Moran 1996; Rugman and Verbeke 2003, p. 130). PF illustrates that firms base their strategy on risk-adjusted transaction costs and real options (Brouthers and Hennart 2007, p. 403; D’Aveni and Ilinitch 1992, p. 597). Under certain circumstances, as found in large infrastructure investments, risk reduction can be the key driver of strategy, rather than transaction cost efficiency. Since firms differ in the degree to which they can manage a certain sources of risk, cooperating with firms that dispose of superior risk-management capabilities can be economically feasible, despite potentially higher costs. Further research in IB should put more emphasis on important firm-specific advantages in terms of risk management and finance (Rugman 1980). Acknowledging these firm-specific advantages would help IB researchers to learn why some invest- 
ments are made despite high transaction costs and why some companies are more capable of taking on risks from uncertain (risky) environments.

Third and finally, PF clearly illustrates the pivotal role of lenders in financing foreign investments in risky contexts. This is in stark contrast to contemporary IB research, which commonly focuses very strongly on equity side strategies (e.g. joint ventures). The role of the liabilities' side and the actors that it inevitably connects to the investment is often disregarded (Agmon 2006; Krugman 1985). PF is practical proof that lenders can serve as political allies and providers expertise. Future IB and Management research needs to address the important role of the liabilities' side as a strategic complement to equity-based strategies. Additionally, Management research on international investments would benefit from addressing the pivotal role of debt providers in the dynamics of megaprojects' failures. In his ground-breaking work on finance and governance, Williamson (1988, p. 580) recognized that "debt is unforgiving if things go poorly. Failure to make scheduled payments thus results in liquidation" and yet, the pivotal role of lenders in the failure of projects has not been sufficiently acknowledged in Management or in IB research. In addressing the role of lenders, research could gain important insights on the boundary conditions of strategy. In the long run, the opportunities and resources that are available companies in the process of internationalization depend not only on their assets, but also on their ability to finance risky investments.

Concluding, it can be summarized that PF offers not only a superior empirical setting for Finance, Management and IB research. It also instigates important theoretical contributions for both disciplines. Interdisciplinary perspectives, in particular, can help to advance our understanding of the financing and management of risky investments. $\mathrm{PF}$ involves the most complex and challenging projects of our time, often in high-risk environments. It has repeatedly challenged the frontiers of financing and management practice, and it is time that research makes appropriate use of PF in order to test the boundary conditions of existing theories.

Acknowledgements Open access funding provided by Vienna University of Economics and Business (WU).

Open Access This article is distributed under the terms of the Creative Commons Attribution 4.0 International License (http://creativecommons.org/licenses/by/4.0/), which permits unrestricted use, distribution, and reproduction in any medium, provided you give appropriate credit to the original author(s) and the source, provide a link to the Creative Commons license, and indicate if changes were made.

\section{References}

Agmon T (2006) Bringing financial economics into international business research: taking advantage of a paradigm change. J Int Bus Stud 37:575-577

Ahola T, Davies A (2012) Insights for the governance of large projects. Int J Manag Proj Bus 5:661-679

Ahuja G, Polidoro F Jr, Mitchell W (2009) Structural homophily or social asymmetry? The formation of alliances by poorly embedded firms. Strateg Manag J 30:941

Alcacer J, Ingram P (2013) Spanning the institutional abyss: the Intergovernmental network and the governance of foreign direct investment. Am J Sociol 118:1055-1098

Anderson E, Gatignon H (1986) Models of foreign entry: transaction cost analysis and propositions. J Int Bus Stud 17:1-26 
Arndt C, Chinowsky P, Strzepek K, Thurlow J (2012) Climate change, growth and infrastructure investment: the case of Mozambique. Rev Dev Econ 16:463-475

Banal-Estañol A, Ottaviani M, Winton A (2013) The flip side of financial synergies: coinsurance versus risk contamination. Rev Financ Stud 26(12):3142-3181

Barney JB (1991) Firm resources and sustained competitive advantage. J Manag 17:99-121

Basel Committee on Banking Supervision (2004) International convergence of capital measurement and capital standards - a revised framework, vol June. Bank for International Settlements, Basel

Beidleman CR, Fletcher D, Vesbosky D (1990) On allocating risk-the essence of project finance. Sloan Manag Rev 31:47-55

Bell GR, Filatotchev I, Rasheed A (2012) The liability of foreignness in capital markets: sources and remedies. J Int Bus Stud 43:107-122

Bell RG, Filatotchev I, Rasheed AA (2010) Liability of foreignness: new insights from capital markets-the past, present and future of International Business \& Management. Adv Int Manag 23:293-326

Berkovitch E, Kim EH (1990) Financial contracting and leverage induced over- and under-investment incentives. J Financ 45:765-794

Berry H, Guillén MF, Nan Z (2010) An institutional approach to cross-national distance. J Int Bus Stud 41:1460-1480

Blanc-Brude F, Strange R (2007) How banks price loans to public-private partnerships: evidence from the european markets. J Appl Corp Financ 19:94-106

Brealey RA, Cooper IA, Habib MA (1996) Using project finance to fund infrastructure investments. J Appl Corp Financ 9:25-39

Brouthers KD, Brouthers LE, Werner S (2008) Resource-based advantages in an international context. J Manag 34:189-217

Brouthers KD, Hennart J-F (2007) Boundaries of the firm: insights from international entry mode research. J Manag 33:395-425

Byoun S, Kim J, Yoo SS (2013) Risk management with leverage: Evidence from project finance. J Financ Quant Anal 48:549-577

Byoun S, Xu Z (2014) Contracts, governance, and country risk in project finance: theory and evidence. J Corp Financ 26:124-144

Chan CM, Makino S (2007) Legitimacy and multi-level institutional environments: implications for foreign subsidiary ownership structure. J Int Bus Stud 38:621-638

Chemmanur TJ, John K (1996) Optimal incorporation, structure of debt contracts, and limited-recourse project financing. J Financ Intermed 5:372-408

Chen C (2009) Can the pilot BOT Project provide a template for future projects? A case study of the Chengdu No. 6 Water Plant B Project. Int J Proj Manag 27:573-583

Chung CC, Beamish PW (2012) Multi-party international joint ventures: multiple post-formation change processes. J World Bus 47:648-663

Coase R (1998) The new institutional economics. Am Econ Rev 88:72-74

Corielli F, Gatti S, Steffanoni A (2010) Risk shifting through nonfinancial contracts: effects on loan spreads and capital structure of project finance deals. J Money Credit Bank 42:1295-1320

Crook TR, Combs JG, Ketchen DJ, Aguinis H (2013) Organizing around trasaction costs: What we have learned and where do we go from here? Acad Manag Perspect 27:63-79

D'Aveni RA, Ilinitch AY (1992) Complex patterns of vertical integration in the forest products industry: systematic and bancruptcy risk. Acad Manag J 35:596-625

Dailami M, Hauswald R (2007) Credit-spread determinants and interlocking contracts: a study of the Ras Gas project. J Financ Econ 86:248-278

Dailami M, Leipziger D (1997) Infrastructure project finance and capital flows: a new perspective. In: World bank policy research working paper, vol 1861. World Bank, Washington

Das TK, Bing-Sheng T (2000) A resource-based theory of strategic alliances. J Manag 26:31-62

David RJ, Han SK (2004) A systematic assessment of the empirical support for transaction cost economics. Strateg Manag J 25:39-58

Davies A, Gann D, Douglas T (2009) Innovation in megaprojects: systems integration at London heathrow terminal 5. Calif Manag Rev 51:101-125

Davies A, Mackenzie I (2014) Project complexity and systems integration: constructing the London 2012 Olympics and Paralympics Games. Int J Project Manag 32:773-790

DiMaggio PJ, Powell WW (1983) The iron cage revisited: institutional isomorphism and collective rationality in organizational fields. Am Sociol Rev 48:147-160 
Djankov S, Glaeser E, La Porta R, Lopez-de-Silanes F, Shleifer A (2003) The new comparative economics. J Comp Econ 31:595

Doh JP, Ramamurti R (2003) Reassessing risk in developing country infrastructure. Long Range Plan 36:337-353

Eisenhardt KM, Schoonhoven CB (1996) Resource-based view of strategic alliance formation: strategic and social effects in entrepreneurial firms. Organ Sci 7:136-150

Emerson RM (1962) Power-dependence relations. Am Sociol Rev 27:31-41

Esty B (2002) Returns on project-financed investments: evolution and managerial implications. J Appl Corp Financ 15:71-86

Esty B, Chavich C, Sesia A (2014) An overview of project finance and infrastructure finance-2014 Update. In: Working paper. Harvard Business School, Boston

Esty BC (1999a) Improved techniques for valuing large-scale projects. J Proj Financ 5:17-26

Esty BC (1999b) Petrozuata: a case study of effective use of project finance. J Appl Corp Financ 12:26-42

Esty BC (2001) Structuring loan syndicates: a case study of the Hong Kong Disneyland project loan. J Appl Corp Financ 14:80-95

Esty BC (2003) The economic motivations for using project finance. In: Working Paper. Harvard Business School, Boston

Esty BC (2004a) Modern project finance: a casebook. Wiley, New York, NY (Wiley internat. ed. ed.)

Esty BC (2004b) Why study large projects? An introduction to research on project finance. Eur Financ Manag 10:213-224

Esty BC, Megginson WL (2000) Syndicate structure as a response to political risk in the project finance loan market. Harvard Business School, Boston

Esty BC, Megginson WL (2003) Creditor rights, enforcement, and debt ownership structure: evidence from the global syndicated loan market. J Financ Quant Anal 38:37-59

Esty BC, Sesia A (2011) An overview of project finance and infrastructure finance-2009 update. In: Working paper. Harvard Business School Publishing, Cambridge

Fama EF (1990) Contract costs and financing decisions. J Bus 63:S71-S91

Farrell M (2003) Principal-agency risk in project finance. Int J Project Manag 21:547-561

Fisman R (2001) Estimating the value of political connections. Am Econ Rev 91:1095

Fisman R, Wang YX (2015) The mortality cost of political connections. Rev Econ Stud 82:1346-1382

Flyvbjerg B (2011) Over budget, over time, over and over again: managing major projects. In: Morris PWG, Pinto JK, Söderlund J (eds) The Oxford handbook of project management. Oxford University Press, Oxford, pp 321-344

Flyvbjerg B (2014a) Megaproject planning and management: essential readings. In: Cheltenham [u.a.], Elgar

Flyvbjerg B (2014b) What you should know about megaprojects and why: an overview. Proj Manag J 45:6-19

Flyvbjerg B (2014c) Megaproject planning and management: essential readings. 1. In: Cheltenham [u.a.], vol 1. Elgar, pp XXXIV, $617 \mathrm{~S}$

Flyvbjerg B (2014d) Megaproject planning and management : essential readings. 2. In: Cheltenham [u.a.], vol 2. Elgar, pp XI, $732 \mathrm{~S}$

Flyvbjerg B, Bruzelius N, Rothengatter W (2003) Megaprojects and risk: an anatomy of ambition. Cambridge University Press, Cambridge (1. publ., repr. ed.)

Flyvbjerg B, Garbuio M, Lovallo D (2009) Delusion and deception in large infrastructure projects: two models for explaining and preventing executive disaster. Calif Manag Rev 51:170-193

Gargiulo M (1993) Two-step leverage: managing constraint in organizational politics. Adm Sci Q 38:1-19

Gatti S (2013) Project finance in theory and practice designing, structuring, and financing private and public projects. Academic Press, Waltham (2. ed. ed.)

Gatti S, Kleimeier S, Megginson WL, Steffanoni A (2013) Arranger certification in project finance. Financ Manag 42(1):1-40

Gatti S, Rigamonti A, Saita F, Senati M (2007) Measuring value-at-risk in project finance transactions. Eur Financ Manag 13:135-158

Ghoshal S, Moran P (1996) Bad for practice: a critique of the transaction cost theory. Acad Manag Rev 21:13-47

Gkeredakis E (2014) The constitutive role of conventions in accomplishing coordination: insights from a complex contract award project. Organ Stud 35:1473-1505 
Glaeser EL, La Porta R, Lopez-de-Silanes F, Shleifer A (2004) Do institutions cause growth? J Econ Growth 9:271-303

Granovetter M (1985) Economic action and social structure: the problem of embeddedness. Am J Sociol 91:481-510

Gulati R (1995) Social structure and alliance formation patterns: a longitudinal analysis. Adm Sci Q 40:619652

Haack P, Schoeneborn D, Wickert C (2012) Talking the talk, moral entrapment, creeping commitment? Exploring narrative dynamics in corporate responsibility standardization. Organ Stud 33:815-845

Hainz C, Kleimeier S (2006) Project finance as a risk-management tool in international syndicated lending. In: Discussion paper on governance and the efficiency of economic systems. CESifo (Center for Economic Studies and Ifo Institute for Economic Research), Munich

Hainz C, Kleimeier S (2012) Political risk, project finance, and the participation of development banks in syndicated lending. J Financ Intermed 21:287-314

Han TJS (2003) Infrastructure investment as a real options game: the case of European airport expansion. Financ Manag 32:27-57

Hart O (2001) Financial contracting. In: National Bureau of Economic Research

Heidl RA, Steensma HK, Phelps C (2014) Divisive faultlines and the unplanned dissolutions of multipartner alliances. Organ Sci 25:1351-1371

Henisz WJ (2002) The institutional environment for infrastructure investment. Ind Corp Change 11:355-389

Henisz WJ (2014) Corporate diplomacy: building reputations and relationships with external stakeholders. Greenleaf Publishing, Sheffield

Henisz WJ, Dorobantu S, Nartey LJ (2014) Spinning gold: the financial returns to stakeholder engagement. Strateg Manag J 35:1727-1748

Hennart J-F (1982) A theory of multinational enterprise. University of Michigan Press, Ann Arbor

Hennart J-F (2010) Transaction cost theory and international business. J Retail 86:257-269

Inoue CFKV, Lazzarini SG, Musacchio A (2013) Leviathan as a minority shareholder: firm-level implications of state equity purchases. Acad Manag J 56:1775-1801

James BE, Vaaler PM (2013) Minority rules: state ownership and foreign direct investment risk mitigation strategy In: Columbia FDI perspectives. Vale Columbia Center on Sustainable International Investment, New York

Jenkins B (1986) Reexamining the obsolescing bargain-a study of Canada national energy program. Int Org 40:139-165

Jensen MC (1986) Agency costs of free cash flow, corporate finance, and takeovers. Am Econ Rev 76:323329

Jensen MC, Meckling WH (1976) Theory of the firm: managerial behavior, agency costs and ownership structure. J Financ Econ 3:305-360

John TA, John K (1991) Optimality of project financing: theory and empirical implications in finance and accounting. Rev Quant Financ Account 1:51-74

Kaplan SN, Strömberg P (2003) Financial contracting theory meets the real world: an empirical analysis of venture capital contracts. Rev Econ Stud 70:281-315

Kardes I, Ozturk A, Cavusgil ST, Cavusgil E (2013) Managing global megaprojects: complexity and risk management. Int Bus Rev 22:905-917

Kensinger J (1999) International investment-value creation and appraisal: a real options approach. J Financ 54:2387-2389

Kensinger JW, Martin JD (1988) Project finance: raising money the old-fashioned way. J Appl Corp Financ 1:69-81

Kleimeier S, Megginson WL (2000) Are project finance loans different from other syndicated credits? J Appl Corp Financ 13:75-87

Kleimeier S, Versteeg R (2010) Project finance as a driver of economic growth in low-income countries. Rev Financ Econ 19:49-59

Knight F (1921) Risk, uncertainty and profit. Houghton Mifflin Company, Chicago

Kogut B, Kulatilaka N (1994) Operating flexibility, global manufacturing, and the option value of a multinational network. Manag Sci 40:123-139

Koka BR, Prescott JE (2002) Strategic alliances as social capital: a multidimensional view. Strateg Manag J 23:795-816

Kostova T (1999) Transnational transfer of strategic organizational practices: a contextual perspective. Acad Manag Rev 24:308-324 
Kostova T, Roth K, Dacin MT (2008) Institutional theory in the study of multinational corporations: a critique and new directions. Acad Manag Rev 33:994-1006

Kostova T, Roth K, Dacin MT (2009) Theorizing on MNCs: a promise for institutional theory. In: Academy of management, vol 34, pp 171-173

Kostova T, Zaheer S (1999) Organizational legitimacy under conditions of complexity: the case of the multinational enterprise. Acad Manag Rev 24:64-81

Kraus A, Litzenberger RH (1973) A state-preference model of optimal financial leverage. J Financ 28:911922

Krugman P (1985) International debt strategies in an uncertain world. In: Smith GW, Cuddington JD (eds) International debt and the developing countries - a world bank symposium. Washington, pp 79-100

La Cour LF, Müller J (2014) Growth and project finance in the least developed countries. Int J Econ Sci Appl Res 7:77-103

La Porta R, Lopez-de-Silanes F, Shleifer A (1999) Corporate ownership around the world. J Financ 54:471

La Porta R, Lopez-de-Silanes F, Shleifer A, Vishny R (2000) Investor protection and corporate governance. J Financ Econ 58:3-27

La Porta R, Lopez-de-Silanes F, Shleifer A, Vishny RW (1998) Law and finance. J Polit Econ 106:1113-1155

Lavie D, Rosenkopf L (2006) Balancing exploration and exploitation in alliance formation. Acad Manag J 49:797-818

Leland HE (2007) Financial synergies and the optimal scope of the firm: implications for mergers, spinoffs, and structured finance. J Financ 62:765-807

Lenz L, Munyehirwe A, Peters J, Sievert M (2017) Does large-scale infrastructure investment alleviate poverty? Impacts of Rwanda's electricity access roll-out program. World Dev 89:88-110

Lerner J, Sorensen M, Strömberg P (2008) Private equity and long-run investment: the case of innovation. World Econ Forum Glob Altern Invest 1:27-42

Li J, Rugman AM (2007) Real options and the theory of foreign direct investment. Int Bus Rev 16:687-712

Lyles MA, Steensma HK (1996) Competing for large-scale infrastructure projects in the emerging Asian markets: factors of success. Columbia J World Bus 31:64-75

Marquis C (2003) The pressure of the past: network imprinting in intercorporate communities. Adm Sci Q 48:655-689

Marquis C, Raynard M (2015) Institutional strategies in emerging markets. Acad Manag Ann 9:291-335

Marquis C, Tilcsik A (2013) Imprinting: toward a multilevel theory. Acad Manag Ann 7:195-245

Meyer KF, Estrin S, Bhaumik SK, Peng MW (2009) Institutions, resources, and entry strategies in emerging economies. Strateg Manag J 30:61

Miller R, Lessard DR (2001) Understanding and managing risks in large engineering projects. Int J Proj Manag 19:437-443

Modigliani F, Miller MH (1958) The cost of capital, corporation finance and the theory of investment. Am Econ Rev 48:261-298

Mohr A, Wang C, Goerzen A (2016) The impact of partner diversity within multiparty international joint ventures. Int Bus Rev 25:883-894

Moody's (2015) Default and recovery rates for project finance bank loans, 1983-2014. In: Default reports. Moody's Investor Service, New York

Müllner J (2016) From uncertainty to risk — a risk management framework for market entry. J World Bus $51: 800-814$

Myers SC (1984) The capital structure puzzle. J Financ 39:575-592

Naylor MJ, Chen J, Boardman J (2015) Real options in foreign investment: a South American case study. J Appl Corp Financ 27:110-120

Nell PC, Puck J, Heidenreich S (2015) Strictly limited choice or agency? Institutional duality, legitimacy, and subsidiaries' political strategies. J World Bus 50:302-311

Nevitt PK, Fabozzi FJ (2000) Project financing, 7th edn. Euromoney Books, London

North DC (1981) Structure and change in economic history. Norton

North DC (1995) The new institutional economics and third world development. In: The new institutional economics and third world development, vol 21. Routledge, London and New York

O'Sullivan N, O'Dwyer B (2015) The structuration of issue-based fields: social accountability, social movements and the equator principles issue-based field. Account Organ Soc 43:33-55

Poppo L, Zenger T (2002) Do formal contracts and relational governance function as substitutes or complements? Strateg Manag J 23:707-725 
Project Finance International (2016) League tables. http://www.pfie.com/Journals/2016/01/26/c/b/y/ PFI-Financial-League-Tables-2015.pdf

Ramamurti R (2001) The obsolescing 'bargaining model'? MNC-host developing country relations revisited. J Int Bus Stud 32:23-39

Ramamurti R, Doh JP (2004) Rethinking foreign infrastructure investment in developing countries. J World Bus 39:151-167

Rangan S, Sengul M (2009) The influence of macro structure on the foreign market performance of transnational firms: the value of IGO connections, export dependence, and immigration links. Adm Sci Q 54:229-267

Reuters (2015) Berlin's new airport keeps 2017 target despite delays. In: Reuters Newswire 15.10.2015. Lex Fenwick, New York

Rugman AM (1980) Internalization theory and corporate international finance. Calif Manag Rev 23:73-79

Rugman AM (1981) Inside the multinationals the economics of internal markets. Columbia University Press, New York

Rugman AM, Verbeke A (2003) Extending the theory of the multinational enterprise: internalization and strategic management perspectives. J Int Bus Stud 34:125-137

Salomon R, Wu Z (2012) Institutional distance and local isomorphism strategy. J Int Bus Stud 43:343-367

Sawant RJ (2010) The economics of large-scale infrastructure FDI: the case of project finance. J Int Bus Stud 41:1036-1055

Sawant RJ (2012) Asset specificity and corporate political activity in regulated industries. Acad Manag Rev 37:194-210

Scholtens B (2000) Financial regulation and financial system architecture in Central Europe. J Bank Financ 24:525-553

Scott RW, Levitt RE, Orr RJ (2011) Global projects-institutions and political challenges. Cambridge University Press, Cambridge

Scott WR (1995) Institutions and organizations. Sage, Thousand Oaks

Shah S, Thakor AV (1987) Optimal capital structure and project financing. J Econ Theory 42:209-243

Siegel J (2007) Contingent political capital and international alliances: evidence from South Korea. Adm Sci Q 52:621-666

Smit HTJ (2003) Infrastructure investment as a real options game: the case of european airport expansion. Financ Manag 32:27-57

Sorge M (2004) The nature of credit risk in project finance. In: BIS quarterly review, vol December. Bank of international Settlements, Basel, pp 91-110

Sorge M, Gadanecz B (2008) The term structure of credit spreads in project finance. Int J Financ Econ 13:68-81

Subramanian KV, Tung F (2016) Law and project finance. J FinancI Intermed 25:154-177

Teece DJ (1977) Technology transfer by multinational firms: the resource cost of transferring technological know-how. Econ J 87:242-261

Teece DJ (1986) Transactions cost economics and the multinational enterprise: an assessment. J Econ Behav Organ 7:21-45

Vaaler PM, James BE, Aguilera RV (2008) Risk and capital structure in Asian project finance. Asia Pac J Manag 25:25-50

Vachani S (1995) Enhancing the obsolescing bargain theory: a longitudinal study of foreign ownership of U.S. and European multinationals. J Int Bus Stud 26:159-180

van Marrewijk A (2007) Managing project culture: the case of Environ Megaproject. Int J Project Manag 25:290-299

van Marrewijk A, Clegg SR, Pitsis TS, Veenswijk M (2008) Managing public-private megaprojects: paradoxes, complexity, and project design. Int J Project Manag 26:591-600

Varinder MS, Erramilli MK (2004) Resource-based explaination of entry mode choice. J Mark Theory Pract 12:1-19

Vernon R (1971) Sovereignty at bay the multinational spread of U.S. enterprises. Longman, London

Wells LT, Gleason ES (1995) Is foreign infrastructure investment still risky? Harvard Bus Rev 73:44-55

West J (2015) Capital valuation and sustainability: a data programming approach. Rev Quant Financ Account 45:591-608

Williamson OE (1976) The economics of internal organization: exit and voice in relation to markets and hierarchies. Am Econ Rev 66:278-369 
Williamson OE (1979) Transaction-cost economics: the governance of contractual relations. J Law Econ 22:233-263

Williamson OE (1988) Corporate finance and corporate governance. J Financ 43:567-591

Williamson OE (1996) The mechanisms of governance. Oxford University Press, New York

Woodhouse EJ (2006) The obsolescing bargain redux-foreign investment in the electric power sector in developing countries. NY Univ J Int Law Politics 38:121-221

Wynant L (1980) Essential elements of project financing. Harvard Bus Rev 58:165-173

Yescombe ER (2014) Principles of project finance, 2nd edn. Academic Press, New York

Zaheer S (1995) Overcoming the liability of foreignness. Acad Manag J 38:341-364

Zaheer S (2002) The liability of foreignness, redux: a commentary. J Int Manag 8:351-358 